\title{
In Vitro Recapitulation of Functional Microvessel Using Microfluidic Platform
}

\author{
Xiang Li
}

Follow this and additional works at: https://researchrepository.wvu.edu/etd

\section{Recommended Citation}

Li, Xiang, "In Vitro Recapitulation of Functional Microvessel Using Microfluidic Platform" (2014). Graduate Theses, Dissertations, and Problem Reports. 6070.

https://researchrepository.wvu.edu/etd/6070

This Dissertation is protected by copyright and/or related rights. It has been brought to you by the The Research Repository @ WVU with permission from the rights-holder(s). You are free to use this Dissertation in any way that is permitted by the copyright and related rights legislation that applies to your use. For other uses you must obtain permission from the rights-holder(s) directly, unless additional rights are indicated by a Creative Commons license in the record and/ or on the work itself. This Dissertation has been accepted for inclusion in WVU Graduate Theses, Dissertations, and Problem Reports collection by an authorized administrator of The Research Repository @ WVU.

For more information, please contact researchrepository@mail.wvu.edu. 
Microbial quality and pathogen decontamination strategies for locally-grown, fresh produce from West Virginia and Kentucky

\author{
Ka Wang Li \\ Thesis submitted to the \\ Davis College of Agriculture, Natural Resources and Design \\ At West Virginia University \\ In partial fulfillment of the requirements \\ For the degree of \\ Master of Science \\ In \\ Animal and Nutritional Science \\ Cangliang Shen, Ph.D., Chair \\ Brett P. Kenney, Ph.D. \\ Kristen, Matak, Ph.D. \\ Department of Animal and Nutritional Sciences
}

Morgantown, West Virginia

2017

Keywords: Salmonella, Listeria, Farmers' market, Produce, West Virginia, Kentucky Copyright 2017 KaWang Li 


\title{
ABSTRACT \\ Microbial quality and pathogen decontamination strategies for locally-grown, fresh produce from West Virginia and Kentucky
}

\author{
Ka Wang Li
}

This study aimed to evaluate the microbiological quality/safety of fresh produce from farmers' markets (FM) and assess the post-harvest washing practice with antimicrobials to inactivate Salmonella and Listeria monocytogenes on fresh produce. In study I, 212 produce samples were tested for the presence of Salmonella and Listeria spp. using modified FDA-BAM methods. Aerobic plate counts (APCs), total coliforms (TCCs), and yeast/molds were analyzed on petri-films. Among the 212 samples, the APCs, TCCs, and yeast/molds were 3.72-5.63, 3.675.47, and 3.07-4.13 $\log \mathrm{CFU} / \mathrm{g}$, respectively, with spinach containing the highest $(P<0.05)$ populations. Among all tested samples, Salmonella enterica spp. enterica was detected on $18.6 \%$ of spinach, $10.9 \%$ of tomatoes, $18.5 \%$ of peppers, and $56.3 \%$ of cantaloupes, which is much higher than previous reported. Only $3.78 \%$ of the samples were confirmed for Listeria spp., and $50 \%$ of them were identified as L. monocytogenes, based on multiplex PCR results. Due to the high percentage of pathogens detected on the farmers' marker produce, an evaluation of postharvest produce washing with various antimicrobials was conducted in study II. Specifically, spinach, tomatoes, green peppers and cucumbers were inoculated with $S$. Typhimurium and Tennessee or L. monocytogenes and washed in tap water, vinegar water (10\%), lactic acid (5\%), a lactic and citric acid blend (2.5\%), and sodium hypochlorite (200 ppm) for $30 \mathrm{sec}$ or unwashed. Vinegar water $(10 \%)$ showed better $(P<0.05)$ reduction of $S$. Typhimurium and Tennessee on tomatoes and cucumbers, and L. monocytogenes on tomatoes and peppers than tap water. The three antimicrobials reached an additional reduction level of 0.9 to 2.7 (S. Typhimurium and 
Tennessee) and 0.2 to $1.4 \log \mathrm{CFU} / \mathrm{g}$ ( $L$. monocytogenes) compared to tap water. Lactic acid caused the greatest $(P<0.05)$ reduction of $S$. Typhimurium and Tennessee on spinach and green peppers, and sodium hypochlorite showed the greatest $(P<0.05)$ reduction of $L$. monocytogenes on cucumbers. These results provide important information for FM vendors to develop postharvest protocols to control foodborne pathogens.

Keywords: Salmonella, Listeria, Farmers’ Market, Fresh produce, sanitizers, wash 


\section{ACKNOWLEDGEMENTS}

What a journey, the past two years were extremely fruitful and has been passing by unsettling quickly. I was so fortunate to be surrounded by mentors that genuinely want students to succeed and peers that care and look after one another, basically created a carefree environment for us to exchange ideas and dive deep into the art of food science.

This project would not be made possible without the input from my committee members: Dr. Cangliang Shen's professional guidance and advices were invaluable whenever I got stuck on planning and execution of the experiments. Dr. Brett Kenney's seasoned critical thinking acted as a constant reminder for me to think in multiple perspectives. Dr. Jennifer Weidhaas' expertise in molecular methods brushed up my skills on molecular extraction and quantitative methods. Dr. Kristen Matak's mastery in writing saved me from my broken English. This tiny paragraph couldn't do justice on depicting their support towards my completion in this program, and to that, I am truly grateful.

To all my friends and family, local and international, providing companionship and mental support that transcended time zones and physical distances, thank you for participating in this journey.

This research was supported by the United States Department of Agriculture, National Institute of Food and Agriculture, and AFRI-Food Safety Program (Grant \# 2014-69003-21583). The authors appreciate the Morgantown and Bowling Green Farmers' market Association, and WV Small Farm Center for their generous assistance during the project period. 


\section{TABLE OF CONTENTS}

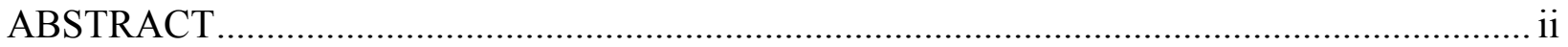

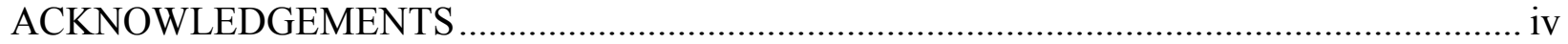

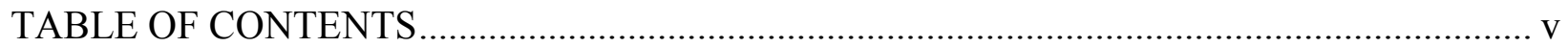

LIST OF TABLES .................................................................................................. viii

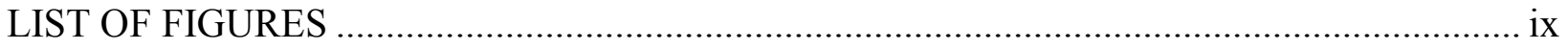

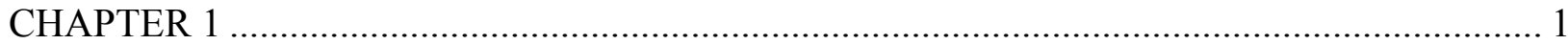

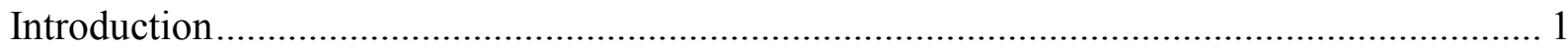

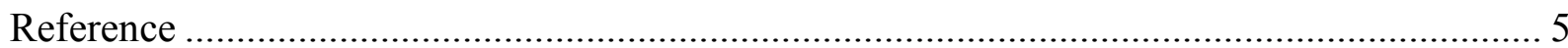

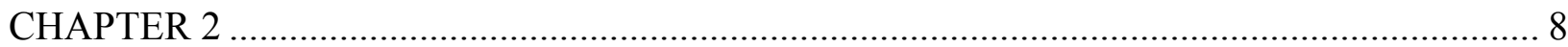

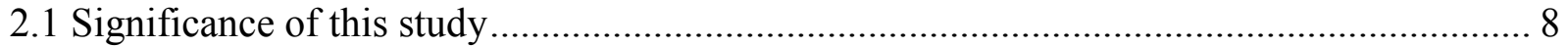

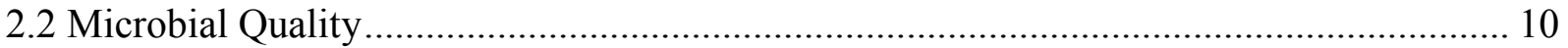

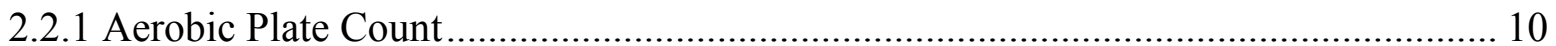

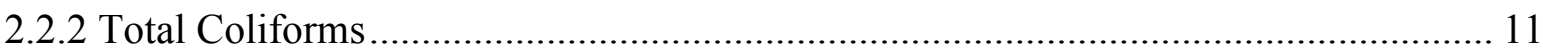

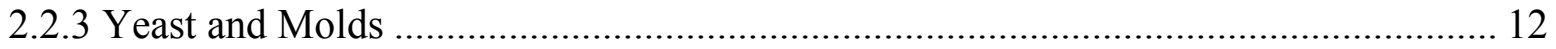

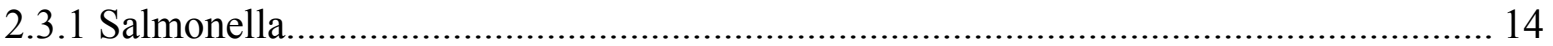

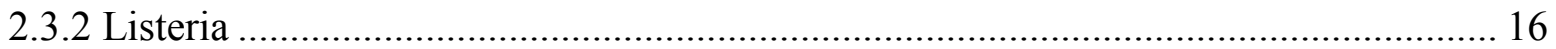

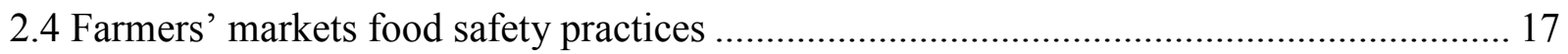

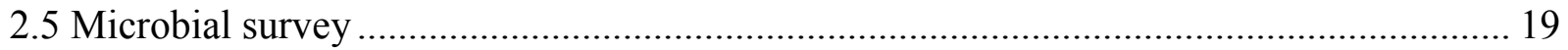

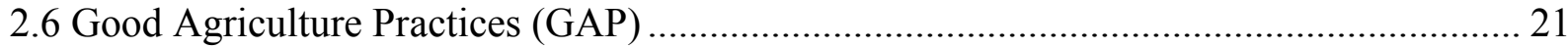




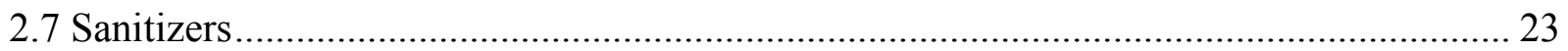

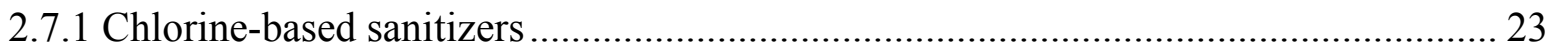

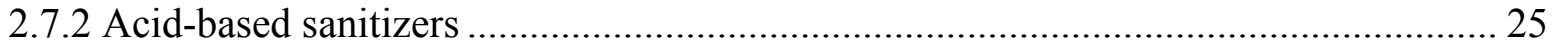

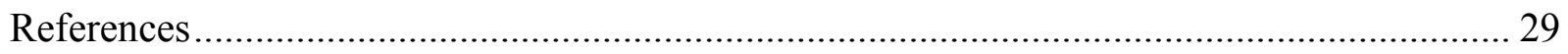

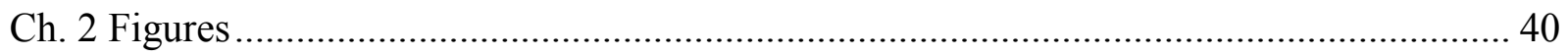

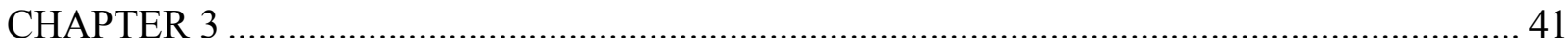

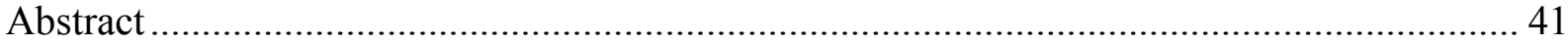

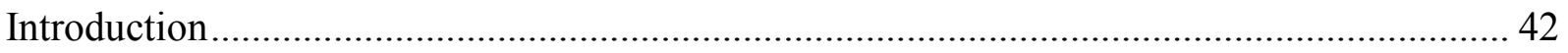

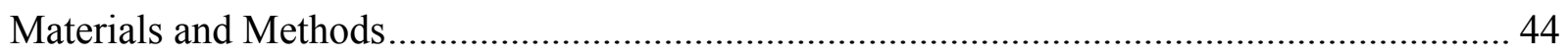

3.1. Fresh produce sample collection and preparation..................................................... 44

3.2. APCs, total coliform and yeast/molds testing of fresh produce.................................... 46

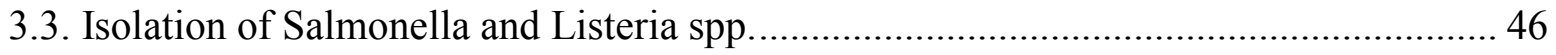

3.4. Molecular identification of Salmonella and Listeria spp............................................. 47

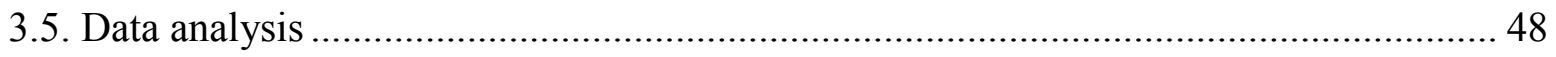

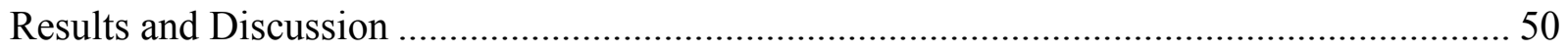

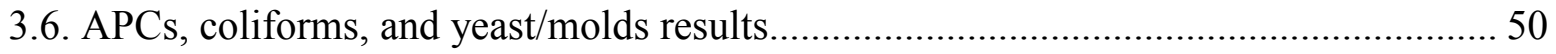

3.7. Salmonella spp. and Listeria spp. prevalence …………………................................. 51

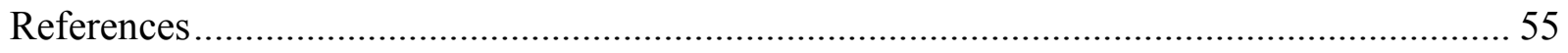

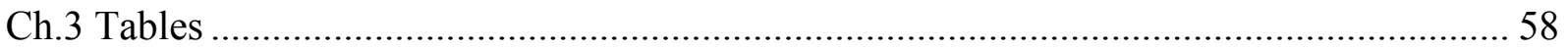

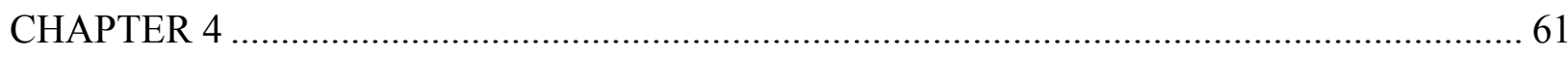


Abstract

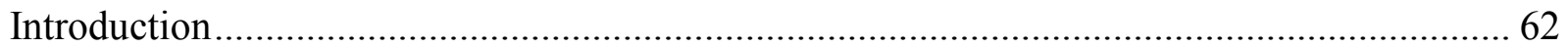

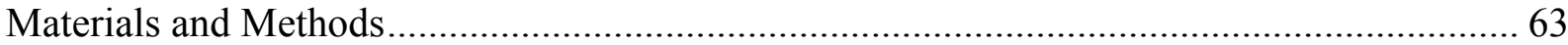

4.1. Inoculation and antimicrobial treatment on fresh produce ...................................... 63

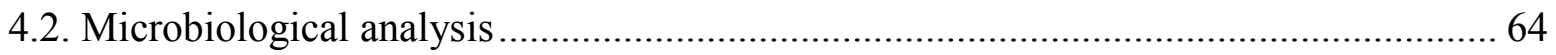

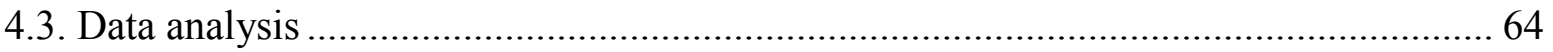

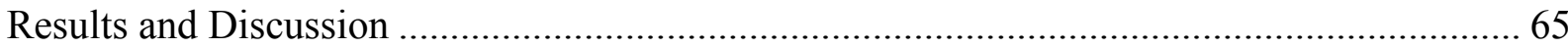

4.4. Efficacy of washing produce without/with antimicrobials to inactivate Salmonella and

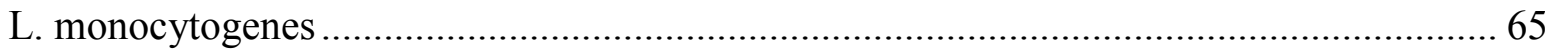

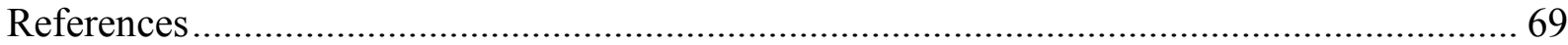

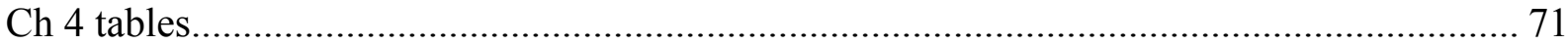




\section{LIST OF TABLES}

\section{CHAPTER 3}

Table 1. Average and standard deviation of microbial populations (log $\mathrm{CFU} / \mathrm{g})$ measured as aerobic plate counts, total coliforms, and yeasts and molds from tomatoes, peppers, cucumbers, cantaloupes and spinach obtained from farmers' markets in Morgantown, West Virginia and Bowling Green, Kentucky.

Table 2. Prevalence of Salmonella enterica spp. on fresh produce obtained from farmers' markets in Morgantown, West Virginia and Bowling Green, Kentucky.

Table 3. Prevalence of Listeria spp. and L. monocytogenes on fresh produce obtained from farmers' markets at Morgantown, West Virginia and Bowling Green, Kentucky.

\section{CHAPTER 4}

Table 4. Survival and reduction of Salmonella Typhimurium and Tennessee populations (log $\mathrm{CFU} / \mathrm{g} \pm$ standard deviation, $\mathrm{n}=8$ ) from spinach, tomatoes, green peppers and cucumbers after being washed with tap water, vinegar (10\%), sodium hypochlorite (SH, $200 \mathrm{ppm})$, lactic acid (LA, 5.0\%), and lactic/citric acid blend (LCA, 2.5\%) solutions for $30 \mathrm{sec}$.

Table 5. Survival and reduction of Listeria monocytogenes populations (log CFU/g \pm standard deviation, $\mathrm{n}=8$ ) from spinach, tomatoes, green peppers and cucumbers after being washed with tap water, vinegar (10\%), sodium hypochlorite (SH, $200 \mathrm{ppm})$, lactic acid (LA, 5.0\%), and lactic/citric acid blend (LCA, 2.5\%) solutions for $30 \mathrm{sec}$. 


\section{LIST OF FIGURES}

\section{CHAPTER 2}

Figure 1. National count of operating farmers' markets in USA from 1994 to 2016

Figure 2. pH profile for reactive chlorine species, copied from Kettle et al, 2014 


\section{CHAPTER 1}

\section{Introduction}

The consumption of fresh produce in the U.S. increased significantly from 154.4 to 186 pounds (per capita availability) from 1970 to 2014 (USDA-ERS, 2016). Fresh produce comes from multiple sources and is often consumed without cooking. Therefore, it is risk to cause foodborne disease and must be handled carefully from the farm to the table to ensure that there is no contamination of the produce from the farmer, shipper, processor, foodservice operators and retailers before human consumption and unfortunately in the US, there were approximately 131 outbreaks associated with 20 different fresh produce commodities from 1996 to 2010, resulting in 14,350 illnesses, 1,382 hospitalizations and 34 deaths (U.S. FDA, 2016b).

Over the past 20 years, there has been an increasing demand for "locally grown" food in the United States (J. Scheinberg, Doores, \& Cutter, 2013). The surge of demand for locally produced food has created jobs and opportunities for small agriculture businesses throughout the nation. Therefore, farmers' markets, roadside stands, pick-your-own farms, and communitysupported agriculture are increasing in popularity. According to the United States Department of Agriculture's (USDA) Economic Research Service (ERS), the number of farmers' markets in the USDA National Farmers' market Directory has more than quadrupled since 1994. Nearly 8,700 farmers' markets operated in 2016, up from 6,100 in 2010, and 1,800 markets in 1994 (USDAERS, 2017). USDA estimated that the total domestic locally produced food sales reached at least \$12 billion in 2014, and it is estimated to achieve the \$20 billion target by 2019 (USDA-AMS, 2016a). Undoubtedly, fresh produce sales dominate the farmers' market landscape, and shopping at a farmers' market is a convenient and economical way to obtain locally grown fresh fruit and vegetables for families. 
As farmers' markets have become more popular, there has been increasing concern regarding microbial safety of available produce. In 2008, Campylobacter contamination in raw bagged peas caused 18 people to become ill at five south-central Alaska farmers' markets (Gardner et al., 2011). In 2011, strawberries contaminated with Escherichia coli O157:H7 and sold at a farmers' market in Oregon sickened 16 people and caused 1 death (Food Safety News, 2011). A recent study in 2014 reported that one Salmonella spp. was confirmed on fresh herbs sampled from 13 farmers' market on the west coast of the U.S. (Levy et al., 2015). In 2015, an E. coli $\mathrm{O} 157: \mathrm{H} 7$ outbreak linked to a food truck serving several farmers' markets in Seattle, WA, resulted in 6 illness and 3 hospitalization (Food Safety News, 2015).

Farmers' markets are a very important agriculture business in West Virginia, creating an average annual revenue of $\$ 41,200$ for full time produce farmers and approximately $\$ 20,000$ for part time farmers (internal unpublished data). Morgantown, the second largest city in WV, has 6 farmers' markets opening from Monday to Saturday. The Morgantown, WV farmers' markets each contain 5 to 35 vendors with half of their total gross sales generated from vegetables and fruits. In Kentucky, there are more than 159 farmers' markets across the state (KY Department of Agriculture, 2016). Bowling Green, the third largest city in KY, has three farmers' markets which are open on Tuesday and Saturday. The Bowling Green, KY markets have approximately 100 vendors with $45 \%$ of them selling fresh produce. Our recent Good Agriculture Practices (GAP) survey of 160 small-scale, produce growers in 21 counties across KY indicated that $90 \%$ of the growers were familiar with GAPs, but only $47 \%$ opted to practice water quality GAPs and only $55 \%$ choose to observe soil amendment GAPs. Participants also failed to identify many sources of potential microbiological contamination including soil, ice, and cooling and refrigeration (only 28-41\% recognition) (Vincent et al., 2015). Therefore, to protect the produce 
in farmers' markets from food safety risks, it is important to assess and understand the risks of foodborne pathogen contamination during vendor produce handling. Further, no information is available regarding presence of pathogens on produce sold at WV and KY farmers' markets.

The new Food Safety Modernization Act (FSMA)-Produce Safety Rule was proposed in 2013 and became effective in 2015 to improve fresh produce safety nationwide (U.S. FDA, 2015). Small produce farms are exempted from the FSMA if the farms 1.) sold $\leq \$ 25,000$ average annual produce during the previous three-year period; 2.) average $<\$ 500,000$ in food sales annually (for the last 3 years); and 3) sell most of their food directly to consumers, restaurants and stores within the state or 275 miles or less from the farm (U.S. FDA, 2015). However, a farm with a qualified FSMA exemption is still required to have their information (name, address, place of produce grown) on the label of their produce. Although the FSMA allows flexibility for small local produce growers, the exemption can be withdrawn if their products have food safety problem or their farm is directly linked to an outbreak as determined by FDA (U.S. FDA, 2015).

Post-harvest produce pathogen control processes are important for small produce growers to reduce pathogens on produce surfaces. The WV Small Farm Center and WV Farmers' market Association organized two short courses on post-harvest produce safety for small growers from 2015 to 2016 (Shen, 2015, 2016). The short course attendants, especially local farmers' market managers, were very interested in knowing the antimicrobial efficacy of commercial antimicrobials on produce surfaces, such as vinegar water. The "three-step" washing process (water, water, followed by antimicrobial application) has been suggested to be effective for removal of pathogens from food surfaces to improve on-farm food safety (Strohbehn et al., 2013). The WV Small Farm Center is also encouraging local small produce growers to apply the 
"three-step" washing procedure if their produce were eaten raw or grown close to the ground (personal communication with Dr. Tom McConnell, Program Leader of the WV Small Farm Center). The effectiveness of antimicrobial chemicals such as chlorine, peracectic acid, lactic acid, acetic acid, citric acid, chlorine dioxide, and ozone has been documented in the new guidelines of the United Fresh Produce Association (Gombas et al., 2017) for industrial scale, fresh cut produce processors. However, efficacy of these antimicrobials to reduce foodborne pathogen risk has not been validated on locally grown fresh produce.

Therefore, the objectives of this study were to 1.) evaluate the prevalence of Salmonella enterica spp. enterica and Listeria spp. as well as amount of aerobic plate counts (APCs), coliforms and yeast/molds on fresh produce obtained from farmers' markets in Morgantown, WV and Bowling Green, KY; and 2.) assess post-harvest washing practices with antimicrobials to control S. Typhimurium and Tennessee and L. monocytogenes on fresh produce from farmers' markets. 


\section{Reference}

Food Safety News. (2011, August 9). Did Deer Cause Oregon's Strawberry Outbreak? Retrieved July 15, 2017, from http://www.foodsafetynews.com/2011/08/epis-pinpoint-strawberriesin-or-e-coli-outbreak/

Food Safety News. (2015, September 4). Update: 9 Confirmed, 1 Probable Case in Seattle E. Coli Outbreak. Retrieved April 27, 2017, from http://www.foodsafetynews.com/2015/09/6-e-coli-cases-linked-to-mexican-food-sold-atwashington-farmers-markets/

Gardner, T. J., Fitzgerald, C., Xavier, C., Klein, R., Pruckler, J., Stroika, S., \& McLaughlin, J. B. (2011). Outbreak of Campylobacteriosis Associated With Consumption of Raw Peas. Clinical Infectious Diseases, 53(1), 26-32. https://doi.org/10.1093/cid/cir249

Gombas, D., Luo, Y., Brennan, J., Shergill, G., Petran, R., Walsh, R., ... Deng, K. (2017). Guidelines To Validate Control of Cross-Contamination during Washing of Fresh-Cut Leafy Vegetables. Journal of Food Protection, 80(2), 312-330. https://doi.org/10.4315/0362-028X.JFP-16-258

KY Department of Agriculture. (2016). Farmers' Market. Retrieved July 15, 2017, from http://www.kyagr.com/marketing/farmers-market.html

Levy, D. J., Beck, N. K., Kossik, A. L., Patti, T., Meschke, J. S., Calicchia, M., \& Hellberg, R. S. (2015). Microbial safety and quality of fresh herbs from Los Angeles, Orange County and Seattle farmers' markets. Journal of the Science of Food and Agriculture, 95(13), 2641-2645. https://doi.org/10.1002/jsfa.6996

Scheinberg, J., Doores, S., \& Cutter, C. N. (2013). A Microbiological Comparison of Poultry Products Obtained from Farmers' Markets and Supermarkets in Pennsylvania: Poultry 
Products from Pennsylvania. Journal of Food Safety, 33(3), 259-264. https://doi.org/10.1111/jfs. 12047

Shen, C. (2015, February). Post-harvest Sanitize and Water Quality. Presented at the West Virginia Small Farm Conference, Charleston Civic Center, West Virginia.

Shen, C. (2016, March). Post-harvest handling. Presented at the West Virginia Farmers Market Manager Training, West Virginia State University, Charleston, West Virginia.

Strohbehn, C., Mendonca, A., Wilson, L., Domoto, P., Smith, M., Brehm-Stecher, B., \& Shaw, A. M. (2013). On-farm Food Safety: Cleaning and Sanitizing Guide. Retrieved from http://lib.dr.iastate.edu/cgi/viewcontent.cgi?article=1101\&context=extension_families_p ubs

U.S. FDA. (2015). Final rule on produce safety. Retrieved July 15, 2017, from https://www.fda.gov/downloads/Food/GuidanceRegulation/FSMA/UCM472887.pdf

U.S. FDA. (2016). Food Safety Modernization Act (FSMA) - Produce Safety Standards [WebContent]. Retrieved July 15, 2017, from https://www.fda.gov/Food/GuidanceRegulation/FSMA/ucm304045.htm\#prevention USDA-AMS. (2016). Local and Regional Food Sector | Agricultural Marketing Service. Retrieved July 15, 2017, from https://www.ams.usda.gov/services/local-regional/foodsector

USDA-ERS. (2016). USDA ERS - Food Availability (Per Capita) Data System. Retrieved July 15, 2017, from https://www.ers.usda.gov/data-products/food-availability-per-capita-datasystem

USDA-ERS. (2017). National count of farmers market directory listings 1994-2016. Retrieved July 15,2017 , from 
https://www.ams.usda.gov/sites/default/files/media/National\%20Count\%20of\%20Operati ng\%20Farmers\%20Markets\%201994-2016.jpg

Z. Vincent, H. Khouryieh, M. Stone, C. Shen, T. William, \& J. Daday. (2015, July). An

assessment of food safety practices at farmers market in Kentucky. Presented at the 2015

annual meeting of the Institute of food technologists, Chicago, IL. 


\section{CHAPTER 2}

\section{Review of Literature}

\subsection{Significance of this study}

The number of farmers' market has been increasing at the national level over the last few decades because of an increased demand for fresh and locally grown produce to support a healthier and sustainable lifestyle. According to data collected by United States Department of Agriculture Agricultural Marketing Service (USDA-AMS) (Figure 1), the number of listed farmers' markets has increased from less than 2000 in 1994 to near 9000 in 2016.

Farmers' markets provide locally grown fresh produce and locally produced muscle foods (i.e. broilers, chicken wings, beef, rabbit) to their communities, and serve as an additional income to small farmers. With the increase in farmers' market shoppers and vendors, local farmers that sell their fresh produce, which is exempt from state inspection and auditing by third parties, may increase the potential of consumers being exposed to contaminated produce (Peters, Hansen, Clingerman, Hereford, \& Askins, 2012).

Unlike grocery stores, most farmers' markets are held outdoors under a semi-open structure; thus, it is difficult to achieve highly controlled environments to display their merchandise. Without controlled indoor temperature and moisture control, coupled with variation in produce handling practices, adopted by different vendors, and the possible exposure to environmental contamination in the structure, the risk of contaminated produce entering the food chain could be higher comparing to controlled indoor marketing of produce.

According to a Centers for Disease Control and Prevention (CDC), 2011 report, foodborne pathogens were a major cause of disease in the U.S., with 9.4 million foodborne illnesses on record. More than 55,000 hospitalizations, and 1,351 deaths were associated with 
these illnesses (Scallan et al., 2011). An estimated 3.6 million cases were caused by bacteria, and nontyphoidal Salmonella was the leading bacterial foodborne pathogen, estimated to be responsible for 1 million (11\%) foodborne illnesses in the United States each year. Nontyphoidal Salmonella is the leading cause of death by ingesting bacteria-contaminated food product at $28 \%$, followed by $19 \%$ for Listeria monocytogenes, estimated to cause around 1600 domestically acquired foodborne illnesses each year. L. monocytogenes is estimated to cause the highest hospitalization rate of $94 \%$, with an estimated death rate of $15.9 \%$ (Scallan et al., 2011). Since 2008, food sold at farmers' markets have been associated with 7 major foodborne outbreaks and 2 recalls resulting in 80 reported illnesses; one young girl kidney failure and one death (J. A. Scheinberg et al., 2017). Good agriculture practices (GAP) of farmers' market vendors and state and local government regulations and guidelines could play an important role in preventing foodborne outbreaks associated with farmers' markets.

In addition to government regulations, farmers can obtain certifications to verify their production and handling practices and demonstrate their commitment to food safety. While most farmers' markets do not require vendors to be GAP-certified, certifications add value by enabling producers to gain access to larger markets and increase the marketability of a produce because consumers are often willing to pay a premium for products that emotionally resonates to their wellbeing and health (Padel \& Foster, 2005). The WV Department of Agriculture provides programs designed to assist farmers obtaining certification for good agricultural practices (GAP), Good Handling Practices (GHP) and organic production along with Hazard analysis and critical control points (HAACP) training. 


\subsection{Microbial Quality}

While the combination of GAP with other prerequisite programs like Sanitation Standard Operating Procedure (SSOP) and a well-designed HACCP can effectively prevent the occurrence of foodborne pathogen contamination, it is impossible to guarantee zero contamination at any stage of the farm-to-fork continuum. Evaluating the microbial quality of various produce by standard microbial sampling methods plays an important role in reducing the likelihood of contamination. Due to the short shelf life and rapid turn-over rate of fresh produce, rapid sampling methods with high accuracy and reliable results are necessary to keep the microbial quality tests relevant (James M. Jay, Martin J. Loessner, \& David A. Golden, 2005).

\subsubsection{Aerobic Plate Count}

Aerobic Plate Count (APC) measures the amount of non-fastidious aerobes. It is not designed to detect the presence of pathogens, but it is used as an indicator of microbial quality and can reflect the sanitation effectiveness and a food product's shelf-life stability and safety (Bibek Ray \& Arun Bhunia, 2013).

According to a guideline posted in 2000 by the Public Health Laboratory Service (PHLS) Advisory Committee for Food and Dairy Products at the United Kingdom, fresh produce with more than $7 \log$ CFU/g APC is classified as unsatisfactory, and i an inspection of hygiene and handling practices would be recommended. Compared to other ready-to-eat food commodities, including red meats, seafood, poultry and desserts, mix salads have the highest tolerance on the APC (RJ Gilbert et al., 2000).

A Vancouver study found the mean APC of locally grown lettuce was $6.3 \log \mathrm{CFU} / \mathrm{g}$ among 68 samples (Wood, Chen, Friesen, Delaquis, \& Allen, 2015). Another study surveyed 
aerobic bacteria in a retail store located in Japan and found that the majority of their lettuce samples (285/419) ranged from 5-6 log CFU/g (Koseki, Mizuno, Kawasaki, \& Yamamoto, 2011).

\subsubsection{Total Coliforms}

In 1892, E. coli was proposed as an indicator fecal contamination based on their abundance in human and animal feces (Peter Feng, Stephen D. Weagant, Michael A. Grant, \& William Burkhardt, 2013). because enteric bacteria, including Escherichia, Enterobacter, Klebsiella, Citrobacter, and Serratia have similar phenotypic characteristics that are not easily distinguished, they are considered "coliforms" which are Gram-negative, facultative anaerobic rod-shaped bacteria that ferment lactose.

Fecal Coliforms are more accurately specified as a sub-group containing the largely of $E$. coli and some other lactose fermenters (i.e. Klebsiella spp.) (Duncan \& Razzell, 1972). E. coli is used as a more specialized indicator of fecal contamination. Fecal coliforms are used as an indication of fecal contamination, water quality, cleanliness in food-processing environments, and predicting shelf-life stability and safety of food products (Peter Feng et al., 2013).

A survey of Vancouver farmers' markets found 72\% (48/68) samples contained coliforms, with a mean level of $2.1 \log \mathrm{CFU} / \mathrm{g}$ (Wood et al., 2015). Another study sampled basil, parsley and cilantro from Los Angeles, Orange County and Seattle farmers' markets and found 112 samples were contaminated with coliforms (84\%), with an average of $2.45 \log \mathrm{CFU} / \mathrm{g}$.

Cilantro had the highest frequency if coliform detection at 88\% (36/41) (Levy et al., 2015). 


\subsubsection{Yeast and Molds}

Microscopic foodborne yeasts and molds are a diverse group of fungi commonly found in air, soil and decaying vegetation. A majority are strict aerobes, thriving in a wide range of $\mathrm{pH}$ (29) and temperature $\left(10-35^{\circ} \mathrm{C}\right)$ conditions; they can survive when water activity is lower than 0.85 (FDA, 2001; Jay et al., 2009).

Several foodborne yeasts and molds such as Brettanomyces bruxellensis and Aspergillus niger produce mycotoxins that are harmful to human health. The number of mycotoxin outbreaks are not as common in the US due to proper regulations and mycological spoilage outbreaks due to inadequate preservation are rare (M. R. Adams \& M. O. Moss, 2008; Yeni, Acar, Polat, Soyer, \& Alpas, 2014).

A study sampled 130 vegetable samples including different types of lettuce and leafy greens, from a farmers' market in Ararquara, Brazil. They found that yeasts and molds ranged from 4 to $7 \log$ CFU/g (Maffei, Silveira, \& Catanozi, 2013). Similar results were found in another microbial quality survey of vegetables in Brazil, which found 5 to $6 \log \mathrm{CFU} / \mathrm{g}$ of yeasts and molds in 162 minimally processed leafy green samples (Oliveira, Maciel de Souza, Morato Bergamini, \& De Martinis, 2011).

\subsection{Foodborne Pathogens}

The most prevalent foodborne pathogens involved in recent fresh produce outbreaks include Listeria monocytogenes, Salmonella, E coli 0157:H7, STEC E. coli and Campylobacter. (Topè, Rogers, \& Hitter, 2014) Much of the produce from farmers' market is ready-to-eat or requires minimal processing before consumption which reduces the likelihood that consumers 
will cleanse the outer surface of the produce, thereby increasing the chance of consuming foodborne pathogens and causing illnesses.

Foodborne outbreaks caused by contaminated produce pose a threat to public health and well-being, it costs the United States an estimated average of \$39 billion annually (Robert L. Scharff, 2010). Understanding pathogen dynamics in fresh produce can improve awareness and effectively reduce their frequency of detection in the food chain.

One of the strengths of the farmers' market is the vast variety of products provided by different vendors, and the selection will only increase with the growing public interest and participating vendors. In the National Farmers' market Directory compiled by the USDA Agricultural Marketing Service (USDA-AMS), available for public access, statisticians separated the available merchandise into more than 20 categories. Other than common products found in most farmers' markets like fresh produce, baked goods, meats and poultry, there are also specialty items such as honey, nuts, seafood, mushrooms and non-food items including body care products, plants, and art \& crafts available (USDA-AMS, 2017b). In the national farmers' market manager survey conducted by the USDA-AMS in 2013 showed virtually all market managers they surveyed sold locally grown fresh fruits and vegetables in their market, an evidence that fresh produces are the core business model in U.S. farmers' markets (USDA-AMS, 2015b). Although the fresh produce safety plays a large part in preventing foodborne outbreaks from farmers' markets, the outbreaks are not limited to fresh produce. There are reports of microbial hazards sourced from different food items sold in U.S. farmers' markets causing foodborne outbreaks. For example 15 reported cases of Salmonella in contaminated cashew products in California (Food Safety News, 2013), 9 confirmed cases E. coli O157:H7 infection in Seattle related to Mexican food served by food trucks (Food Safety News, 2015), a multi-state 
outbreak in 2012 of Campylobacter found in raw dairy products causing 38 cases of reported illness in Pennsylvania, Maryland, West Virginia and New Jersey (Food Poisoning Bulletin, 2012) and 10 cases Campylobacter outbreaks caused by ingesting raw peas in Alaska in 2008 (Gardner et al., 2011)

\subsubsection{Salmonella}

According to reports from the CDC, Salmonella spp. is estimated to be responsible for a million foodborne illnesses every year in the United States (CDC, 2012) and it is the leading cause of death by foodborne illness in the United States (Scallan et al., 2011). Previous outbreaks in the United States with produce as a vector includes tomatoes, bean sprouts, cantaloupes and more. (James M., Martin J., \& David A., 2006a)

Salmonella was first isolated in 1885 by Dr. Theobald Smith and Dr. Daniel Elmer Salmon while studying swine cholera (FDA-NSTA, 2009). More than 2500 serotypes were reported since 2015 (CDC, 2015). And they are divided into six subspecies (Su \& Chiu, 2007) with most are identified as S. enterica (Le Minor \& Popoff, 1987).

Salmonella is a Gram negative, rod shaped, motile facultative anaerobe, with diameter

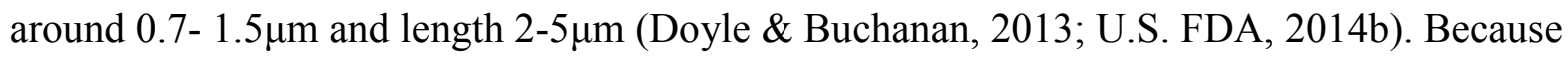
they are in the same family Enterobacteriaceae with E. coli, Salmonella cannot be distinguished from E. coli unless it is cultured in selective or differential media. For example, Salmonella produces a red colony with black center and a diameter around $2 \mathrm{~mm}$ after 24 hours at $37 \mathrm{C}$ incubation on xylose lysine deoxycholate agar (XLD); E. coli appears as yellow colonies (Hardy Diagnostics, 2016). 
The infectious dose of Salmonella is dependent on status of immune system, serotype, and the composition of food as the delivery vehicle, nonetheless records documented a Salmonella infection (salmonellosis) could be caused by less than ten vegetative cells (D'aoust, Warburton, \& Sewell, 1985). Salmonella infections can be acquired through different methods, mainly the consumption of contaminated food ingredients and water (Morris \& Potter, 2013). Salmonellosis occurs when Salmonella cells invades the digestive track, and these cells spread from the intestines to other body parts. Salmonellosis patients generally develop gastroenteritis, including diarrhea, fever and abdominal cramps 12 to 72 hours after infection that lasts 4 to 7 days (James M. et al., 2006a). Severe cases of the infection usually occur in infants, elderly, and those with compromised immune systems which leads to detrimental diarrhea that requires hospitalization and antibiotics treatments. Patients with less severe infections can recover in less than a week when they stay hydrated (Coburn, Grassl, \& Finlay, 2007). The mechanisms behind Salmonella infection and resulting diarrhea is not fully understood, what is currently known came from studies on intestinal structures in animal models (Morris \& Potter, 2013), although there are evidence suggests that ligand interactions play an important role in adherence of Salmonella (Sakarya, 2010).

Most Salmonella infections are from poultry contaminations. A CDC study showed fresh produce to be increasingly involved with around $50 \%$ of illnesses recorded traced back to contaminated produce (IFSAC, 2015; Painter et al., 2013). The CDC has recognized fresh produce as a risky food to consume raw since the 90 s, since they are known to serve as a vehicle for Salmonella and other foodborne pathogens, demonstrated by recurring outbreaks with Salmonella on tomatoes. 


\subsubsection{Listeria}

Listeria spp. contains six species with 17 serotypes: 13 serotypes represents $L$. monocytogenes; and 2 serotypes represents L. innoca and sometimes L. innoca is considered to be a non-pathogenic variant of L. monocytogenes (James M., Martin J., \& David A., 2006b). L. monocytogenes is a gram positive, non-spore forming, psychrotrophic, facultatively anaerobic, motile, short rod (Farber \& Peterkin, 1991). It is $0.4-0.5 \mu \mathrm{m}$ in diameter and $0.5-2 \mu \mathrm{m}$ in length (Schuchat, Swaminathan, \& Broome, 1991). L. monocytogenes is capable of causing listeriosis, an invasive illness in human and animals (Farber \& Peterkin, 1991; Schuchat et al., 1991). L. monocytogenes was first demonstrated to be able to transmit via contaminated food in 1983 (Schlech et al., 1983)

Each year L. monocytogenes cause approximately 1400 hospitalizations and 250 deaths in the United States, it was reported to be one of the leading causes of death from foodborne illness in the United States (19\%) after Salmonella spp. (28\%), and Toxoplasma gondii (24\%) (Scallan et al., 2011). The symptoms for healthy adults are mainly diarrhea and fever; however, it may also to cause abortion and stillbirth in pregnant patients and meningitis and pneumonia in newborns (Gaschignard et al., n.d.; James M. et al., 2006b; Okike, Lamont, \& Heath, 2013).

The psychrotrophic property of L. monocytogenes allows it to survive and grow at refrigerated temperature and reach an infective dose level (as few as 10 million CFU for healthy adults and 0.1 million for the high risk individuals (Farber, Ross, \& Harwig, 1996)) during storage of refrigerated foods that were contaminated. Increased popularity of ready-to-eat foods, improper storage and improper reheating foods, increases the probability of listeriosis. It is known that temporary temperature abuse from improper handling can increase the growth rate of L. monocytogenes (Bibek Ray \& Arun Bhunia, 2013). 
L. monocytogenes can be isolated from many environmental samples including water, soil, decaying vegetation, and animal feces (Farber \& Peterkin, 1991). Foodborne outbreaks of $L$. monocytogenes have been related to contaminated, unpasteurized milk and their products; readyto-eat deli meats; packaged salads; caramel apples; bean sprouts and more (CDC, 2016; Garner \& Kathariou, 2016; USFDA, 2016; Zhu, Gooneratne, \& Hussain, 2017). Through surveillance and monitoring, the U.S. FDA indicated 5\% (21/421) of vegetables and salads and 5.7\% (116/2041) of RTE meats, contain L. monocytogenes (Hitchins, 1996). Due to several outbreaks in the 1980s the U.S. FDA and the USDA FSIS created the zero-tolerance policy for $L$. monocytogenes. These Ready-To-Eat foods are classified as adulterated if L. monocytogenes is detected in one of the two $25 \mathrm{~g}$ samples being tested (U.S. FDA, 2004).

Common L. monocytogenes detection methods include pre-enrichment and enrichment of the samples in recommended broths; these samples are then streaked on selective and differential agar plates (i.e. Modified Oxford Agar). Presumptively positive colonies are selected and tested for biochemical and serological properties (Peter Feng et al., 2013).

\subsection{Farmers' markets food safety practices}

A survey was conducted to study food safety practices of farmers and farmers' market managers from Georgia, Virginia and South Carolina. Out of the 55 markets surveyed, 22 (49\%) markets consisted of more than 15 vendors at their peak season, while 7 markets had 5 or fewer vendors at their peak (Harrison et al., 2013).

Out of the 226 small to medium-sized vendors surveyed, more than half of them $(n=128)$ used manure as fertilizers. Sixty-nine out of 226 (31\%) farmers used untested irrigation sources like streams, ponds, untested wells, and rainwater. Only a minority (88/226) of farmers sanitized 
surfaces that came into contact with produce at their farms. Producers chose vinegar, detergent, soap, diluted bleach solutions, sulfur solutions, citric acid solutions, and ammonia-based solutions. An open ended question showed that the farmers surveyed did not have a clear definition of what classifies as a sanitizer, and they cannot differentiate it from a detergent (Harrison et al., 2013). Detergents soften the soils and promotes dispersion and removal, while sanitizers are treatments that reduce the number of spoilage and pathogenic microorganisms, they do not sterilize the produce or food contact surfaces (Marriott \& Gravani, 2006).

Only one-third (73/226) of the farmers always cleaned the produce transport containers. This lack of hygiene raises concerns of cross-contamination when reusing those containers during transport. While 35\% (79/226) of farmers rarely used any cooling methods during transport, the most popular way to cool produce during transport to farmers' markets was to place produce in a refrigerator or large cooler (125/226) (Harrison et al., 2013).

The survey also asked farmers' market managers if they had established food safety standards for the market, and 19 out of 45 (42\%) did not. In the 19 markets without food safety standards, less than a quarter of them practiced sanitizing market surfaces. Few asked their vendors about sanitation procedures related to employees and produce. Less than a quarter of the markets offered sanitation trainings to their workers and vendors. Only 3 out of $45(6 \%)$ market managers asked if there were any sanitation training courses available to the vendors. A lack of awareness of market managers regarding vendors' food safety practices coupled with the lack of food safety standards set up. Half of the markets surveyed revealed vulnerability and unpreparedness to potential foodborne outbreaks was shown. (Harrison et al., 2013) 


\subsection{Microbial survey}

A microbial safety study involving 13 farmers' markets in Los Angeles and Seattle sampled 133 fresh herbs including basil, cilantro and parsley. All samples were subjected to testing for the presence of Salmonella and E. coli using the Bacteriological Analytical Manual (BAM) and Association of Official Agricultural Chemists (AOAC) method 991.14. 15.

Presumptively positive salmonella samples were recovered, and only one parsley sample was confirmed Salmonella positive by API 20E test (Levy et al., 2015). Of 133 fresh herbs sampled, the majority of them (112) were coliform positive. Thirty-two samples were generic $E$. coli positive, with up to 3.15 and $4.15 \log \mathrm{CFU} / \mathrm{g}$ in Coliform and E. coli, respectively. Based on guidelines for microbial quality of RTE foods established by the Public Health Laboratory Service (PHLS), 16 samples (out of 133) contained more than $2 \log$ CFU/g E. coli, and this level of contamination was unsatisfactory (Levy et al., 2015; Gilbert et al., 2000).

A Vancouver study sampled 68 Romaine lettuce in 5 farmers' markets for level of aerobic bacteria, total coliforms, and E. coli. They isolated E. coli samples were tested to determine phylogenetic groupings and virulence genes using multiplex PCR to detect virulence genes (eaeA, hlyA, stx1, and stx2) (Wood et al., 2015).

Mean APC of lettuce samples was $6.3 \log$ CFU/g and ranged from 4.8 to 7.8 . While $72 \%$ (49) of samples contained Coliforms at a mean of $1.9 \log$ CFU/g and 13\% (9) contained approximately $0.7 \log \mathrm{CFU} / \mathrm{g}$ E. coli. Serial dilutions and 3M Petrifilm were used to enumerate APC, TCC and E. coli (EC). Samples with low levels of E. coli were enriched before enumeration (Wood et al., 2015). 
This study focused multidrug-resistant E. coli in fresh produce. All E. coli were tested for resistance to 15 antibiotics by disk diffusion assay. Antibiogram typing of all E. coli (33 samples) showed 97\% were resistant to one or more antimicrobials (Wood et al., 2015).

A study in Alberta, Canada surveyed 6 types of fresh produce from farmers' market and public markets in urban centers and surrounding areas in Alberta for E. coli and the prevalence of foodborne pathogens (Bohaychuk et al., 2009).

128 Lettuce, 59 spinach, 120 tomatoes, 206 carrots, 129 green onions, and 31 strawberries were collected from 10 large markets with 1 to 12 produce vendors and 26 small markets with 1 to 6 produce vendors. Samples were tested for generic E. coli, Salmonella, E. coli O157:H7, and Campylobacter spp. Lettuce, spinach, green onion, and strawberry samples were also tested for Cryptosporidium spp. E. coli was recovered from $55(8.2 \%)$ of the samples that included lettuce, spinach, carrots, and green onions. Bacterial counts ranged from 0.48 to 3.04 $\log$ CFU/g (Bohaychuk et al., 2009).

Of the samples positive for E. coli, carrots were the least contaminated at 9 positives (4.4\%). Spinach contained the most, with 16 samples testing E. coli positive (27.1\%). Cryptosporidium was identified in one sample of spinach by PCR; authors did not find any Salmonella, E. coli O157:H7, and Campylobacter spp. positive samples (Bohaychuk et al., 2009).

Another study reported the prevalence of Listeria spp. in four, common fresh produce (lettuce, carrot, purple cabbage, and green cabbage) over a 5-week period; samples were collected from two markets in New Zealand every week (Zhu \& Hussain, 2015).

Listeria spp. was detected in all purple cabbage samples, and between $60 \%$ and $100 \%$ of the green cabbage samples depending on the markets. Lettuce samples collected from both 
markets from week 1 to week 3 contained Listeria spp. while no Listeria spp. were detected afterwards. Carrot samples contained the lowest percentage (20\%) of Listeria spp (Zhu \& Hussain, 2015).

Frequency of Listeria spp. detection varies between vegetable types. Purple cabbage had the highest count at $150 \mathrm{CFU} / \mathrm{g}$, while cabbage, lettuce and carrots were $33 \mathrm{CFU} / \mathrm{g}, 87 \mathrm{CFU} / \mathrm{g}$ and $2 \mathrm{CFU} / \mathrm{g}$, respectively. While purple cabbage contained an unusually high level of Listeria spp. compared to other produce types, data suggested Listeria spp. were generally prevalent in fresh produce (Zhu \& Hussain, 2015).

\subsection{Good Agriculture Practices (GAP)}

Good Agriculture Practices (GAP) were first implemented by FDA in the Guide to Minimize Microbial Food Safety Hazards for Fresh Fruits and Vegetables in 1998 (USDA-AMS, 2017a). These practices are preventive measures designed to reduce contamination of fresh produce with foodborne pathogens, thereby reducing possible outbreaks (Omar A. Oyarzabal \& Steffen Backert, 2011). GAP, along with good manufacturing practices (GMP) and good hygienic practices (GHP) are the first steps to developing a Hazard Analysis Critical Control Point (HACCP), a fundamental tool for improving food safety (FAO \& WHO, 2003).

The general idea of GAP has changed with the increasing concerns of food quality, safety, and sustainability among consumers and farmers. GAP is an effective approach to produce wholesome agricultural products by reducing the risk of produce contamination on site (FAO \& WHO, 2003). Implementation of GAP is a regulatory requirement, and private retailers may require third party certification to ensure quality and safety of produce and improve growers' health and working conditions (FAO, 2008). 
The FDA's good agricultural practices guide is based on the following eight principles (U.S. FDA, 1998):

Principle 1. Prevention of microbial contamination of fresh produce is favored over reliance on corrective actions once contamination has occurred.

Principle 2. To minimize microbial food safety hazards in fresh produce, growers, packers, or shippers should use good agricultural and management practices in those areas over which they have control.

Principle 3. Fresh produce can become microbiologically contaminated at any point along the farm-to-table food chain. The major source of microbial contamination with fresh produce is associated with human or animal feces.

Principle 4. Whenever water comes in contact with produce, its source and quality dictates the potential for contamination. Minimize the potential of microbial contamination from water used with fresh fruits and vegetables.

Principle 5. Practices using animal manure or municipal biosolid wastes should be managed closely to minimize the potential for microbial contamination of fresh produce.

Principle 6. Worker hygiene and sanitation practices during production, harvesting, sorting, packing, and transport play a critical role in minimizing the potential for microbial contamination of fresh produce.

Principle 7. Follow all applicable local, state, and Federal laws and regulations, or corresponding or similar laws, regulations, or standards for operators outside the U.S., for agricultural practices.

Principle 8. Accountability at all levels of the agricultural environment (farm, packing facility, distribution center, and transport operation) is important to a successful food safety 
program. There must be qualified personnel and effective monitoring to ensure that all elements of the program function correctly and to help track produce back through the distribution channels to the producer.

These eight principles guide growers in recognizing and addressing problems that lead to microbial food safety problems (U.S. FDA, 1998).

\subsection{Sanitizers}

Sanitizers are a type of antimicrobial treatment alongside with disinfectants commonly used to clean food contact surfaces and the surface of fresh produce. During processing, soil and contaminants can act as a reservoir for pathogens to survive. Applying sanitizers while preparing fresh produce is a critical control point to inactivate pathogens and to improve produce's safety, quality and shelf-life. Sanitizers are effective in destroying vegetative cells and reducing microbial contaminants to levels that are considered to be safe from a public health standpoint. Sanitizers are regulated by the Environmental Protection Agency (EPA). The details on certified commercial sanitizers including their chemical makeup and active ingredients are open to the public and can be found on their website.

\subsubsection{Chlorine-based sanitizers}

Sodium hypochlorite is the active compound in household beach. It is inorganic and commonly used as a disinfectant in food, water and different surfaces. When dissolved in water, sodium hypochlorite ionizes and forms chlorine gas, hypochlorite ions and hypochlorous acid (Marriott \& Gravani, 2006). It is common to treat fresh produce, post-harvest, with a chlorinated solutions as an antimicrobial intervention (Shen, Luo, Nou, Wang, \& Millner, 2013). 
Sodium hypochlorite is generally recognized as safe (GRAS). The U.S. FDA approved its use in washing fresh produce and recommended applying $40-200 \mathrm{mg} / \mathrm{L}$ chlorine solution for 1-2 minutes as sanitizing treatments for produce and equipment (U.S. FDA, 2014c, 2016c). Its residue, free chlorine, is exempt from tolerances when used as pre- and post-harvest treatment for crops (CFR, 2005). As long as the chlorine residue in washing solutions is below $4 \mathrm{ppm}$, the maximum disinfectant limit for drinking water, foods processed with sodium hypochlorite can be labeled as organic by the National Organic Program (NOP) (CFR, 2003).

Hypochlorite ions and hypochlorous acid destroy cells by hydrolyzing cell membranes, reacting with amino acids, and interfering with metabolism and enzyme functions in cells (Estrela et al., 2002). Hypochlorous acid ( $\mathrm{HOCl})$ is the most effective form of chlorine for sanitation; this form is present predominantly at $\mathrm{pH}$ 4-6 (Figure 2). Citric acid is commonly used to adjust the $\mathrm{pH}$ of the chlorine solution (USDA-AMS, 2015a). Depending on the $\mathrm{pH}$ gradient, the reactive chlorine species is dominated by chlorine gas when $\mathrm{pH}$ is below 4.0 and hypochlorite ion when $\mathrm{pH}$ is alkaline (Kettle et al., 2014). Hypochlorous acid's efficiency can also be affected by temperature, light, metals in contact, and presence of oxygen (Parish et al., 2003).

Free chloride is easily consumed by organic matter. The presence of organic matters lowers the concentration of free chlorine rapidly and reduce its sanitation efficacy (Doyle \& Buchanan, 2013; Marriott \& Gravani, 2006). Reaction between free chlorine and organic matter promotes formation of a small amount of harmful by-products, including possible carcinogens like haloacetic acids (HAA) and trihalomethanes (THMs) (Shen et al., 2013)

The efficiency of chlorine-based sanitizers was studied with different application methods and food product types. Investigators observed $3 \log$ CFU/unit reduction in $S$. 
Typhimurium inoculated fresh tomatoes by spraying chlorine solution $(200 \mathrm{mg} / \mathrm{L})$ with a contact time of 30 seconds, and a $3.61 \log$ CFU/unit reduction from immersing the tomatoes in the same chlorine solution (Chaidez, Lopez, Vidales, \& Campo, 2007). Another study, on the dynamic effects of free-chlorine concentration, reported a 4 to $5 \log \mathrm{CFU} / \mathrm{mL}$ reduction of a mixture of Salmonella and E. coli strains at 30 seconds contact time in the presence of fresh produce extract (Shen et al., 2013).

\subsubsection{Acid-based sanitizers}

\subsubsection{Peroxyacetic Acid}

Peroxyacetic acid (PAA), also known as peracetic acid, is a powerful, oxidizer and an effective sanitizer against both gram positive and negative bacteria, as well as yeast and molds, by disrupting chemical bonds in enzymes and cell membrane. It is considered to be a stronger biocide than hydrogen peroxide (McDonnell \& Russell, 1999).

PAA is synthesized from the reaction between acetic acid and hydrogen peroxide. The chemical reactions can produce up to $40 \%$ PAA in solution, with up to $25 \%$ hydrogen peroxide as residue and up to $40 \%$ acetic acid (USDA-AMS, 2016c). There are multiple manufacturing processes for PAA recorded in the literature (USDA-AMS, 2016c), and these products can be used for sanitizing produce, leafy greens, poultry and meats (FAO \& Ma. Patricia V. Azanza, 2004).

PAA has a potent odor, and it is stable in the $100-200 \mathrm{ppm}$ range. Its sanitizing efficiency is reduced when above neutral $\mathrm{pH}$. It has low tolerance to soil and is less compatible with hard water. It has higher organic material tolerance than chlorine-based sanitizers (Marriott \& Gravani, 2006; Oyarzabal \& Backert, 2011). 
PAA is classified as generally recognized as safe (GRAS), and it is limited to no more than $80 \mathrm{ppm}$ in water when assisting the peeling of fruits and vegetables, followed by a rinsing with potable water (U.S. FDA, 2016c). For sanitizing food-processing equipment or food contact articles, the concentration range is permitted within 100-200ppm (U.S. FDA, 2011a).

The efficacy of PAA has been studied with different food products. Applying 500ppm PAA to almonds without agitation caused up to a $1.93 \mathrm{log}$ CFU/g reduction on Salmonella enterica (Pao, Kalantari, \& Huang, 2006), while combining 80ppm PAA with the rolling process for 60 seconds, Salmonella population was reduced by up to $5.5 \log$ CFU/mL (Chang \& Schneider, 2012).

\subsubsection{Organic Acids}

Organic acids are natural and can be found commonly in fruits food products and they are by-products of fermentation. Organic acids like malic acid can be found in apples, lactic acids can be found in dairy products, tartaric acid from grapes, citric acid from lemon, and acetic acid form vinegar (Theron \& Lues, 2011). Organic acids are considered generally recognized as safe (GRAS) by U.S. FDA and are used as preservatives, antioxidants and flavorings; they can found in soft drinks, desserts, salad dressings, and low acid foods as acidulants (Mircea Enachescu Dauthy, 1995; Theron \& Lues, 2011).

The antimicrobial properties of organic acids has been studied with bacteria and fungi. It is known that factors like concentration, $\mathrm{pH}$, organic acid type and method of application played a key role in efficacy of organic acids (Theron \& Lues, 2011). The primary mechanism involves disrupting the proton motive force in the cytoplasmic membrane, interfering with the electron transport chain (ETC) (Doyle \& Buchanan, 2013; Lambert \& Stratford, 1999). A study using nuclear magnetic resonance spectroscopy (NMR) to measure lactate and acetate transport, 
showed evidence of organic acids interfering with the ETC and affecting electron and $\mathrm{pH}$ gradients and reducing ATP production; these effects damaged the membrane of Escherichia coli (Axe \& Bailey, 1995). Low $\mathrm{pH}$ environments lengthen the lag phase and decreases the growth rate of cells (Theron \& Lues, 2011).

Lactic acid is naturally produced by lactic acid bacteria through fermentation, and is mainly used to control pH and add flavoring in food products (Doyle \& Buchanan, 2013). Lactic acid can inhibit spore formers Clostridium butyricum, Staphylococcus aureus, and Yersinia enterocolitica (Brackett, 1987; Hirsch, McClintock, \& Mocquot, 1952; Minor \& Marth, 1970). When comparing inhibition of Bacillus coagulans in tomato juice by organic acids, lactic acid was most effective compared to acetic, malic, and citric acids (Rice \& Pederson, 1954). Another study showed lactic, malic and citric acids are more effective than acetic and propionic acids in a mixture of E. coli, S, Typhimuium and L. monocytogenes (Park et al., 2011).

Effectiveness of lactic acid was also studied on multiple agricultural products with different foodborne pathogens. A 5-minute wash with $1 \%$ lactic acid can reduce $E$. coli by 2.7 $\log$ CFU/g on baby spinach (Huang \& Chen, 2011). Another study showed that 10 minutes of $2 \%$ lactic acid treatment of apples can reduce a mixture E. coli, S, Typhimuium and $L$. monocytogenes by up to $3.42 \log$ unit. In the same study, $2 \%$ lactic acid in a 10-minute treatment on lettuce reduced the same bacteria mixture by up to $2.54 \log$ CFU/units (Park et al., 2011).

While acid-based sanitizers are generally effective on bacteria, strains like Salmonella Typhimurium and S. enteritidis are able to adapt to acidic environments and survive better than their non-adapted counterparts on lactic acid fermented foods and common food preservative like EDTA (Ethylenediaminetetraacetic acid), at a low dosage (Leyer \& Johnson, 1992, 1997). 
To sum up, prevalence of pathogens in farmers' market is low but it should not be a factor for us to overlook. Executing Good Agriculture Practices (GAPs), as well as studying the characteristics of foodborne pathogens and sanitizing fresh produce and food contact surfaces should contribute decreasing the chance of contaminating fresh produce with foodborne pathogens. 


\section{References}

Axe, D. D., \& Bailey, J. E. (1995). Transport of lactate and acetate through the energized cytoplasmic membrane ofEscherichia coli. Biotechnology and Bioengineering, 47(1), 8-19. https://doi.org/10.1002/bit.260470103

Bibek Ray, \& Arun Bhunia. (2013). Fundamental Food Microbiology (Fifth Edition).

Bohaychuk, V. M., Bradbury, R. W., Dimock, R., Fehr, M., Gensler, G. E., King, R. K., ... Barrios, P. R. (2009). A Microbiological Survey of Selected Alberta-Grown Fresh Produce from Farmers' Markets in Alberta, Canada. Journal of Food Protection, 72(2), 415-420. https://doi.org/10.4315/0362-028X-72.2.415

BRACKETT, R. E. (1987). Effects of various acids on growth and survival of Yersinia enterocolitica. Journal of Food Protection, 50(7), 598-601.

CDC. (2012, January). pathogens-complete-list-01-12.pdf. Retrieved from https://www.cdc.gov/foodborneburden/PDFs/pathogens-complete-list-01-12.pdf

CDC. (2015, March 9). Serotypes and the Importance of Serotyping Salmonella | CDC. Retrieved April 29, 2017, from https://www.cdc.gov/salmonella/reportspubs/salmonella-atlas/serotypingimportance.html

CDC. (2016). Multistate Outbreak of Listeriosis Linked to Packaged Salads Produced at Springfield, Ohio Dole Processing Facility. Retrieved May 23, 2017, from https://www.cdc.gov/listeria/outbreaks/bagged-salads-01-16/

CFR. (2003). 7 CFR 205.605 - Nonagricultural (nonorganic) substances allowed as ingredients in or on processed products labeled as "organic" or "made with organic (specified ingredients or food group(s))." Retrieved July 6, 2017, from https://www.law.cornell.edu/cfr/text/7/205.605

CFR. (2005). 40 CFR 180.1235 - Sodium hypochlorite; exemption from the requirement of a tolerance. Retrieved April 6, 2017, from https://www.law.cornell.edu/cfr/text/40/180.1235 
Chaidez, C., Lopez, J., Vidales, J., \& Campo, N. C.-D. (2007). Efficacy of chlorinated and ozonated water in reducing Salmonella typhimurium attached to tomato surfaces. International Journal of Environmental Health Research, 17(4), 311-318. https://doi.org/10.1080/09603120701417063

Chang, A. S., \& Schneider, K. R. (2012). Evaluation of Overhead Spray-Applied Sanitizers for the Reduction of?Salmonella?on Tomato Surfaces. Journal of Food Science, 77(1), M65-M69. https://doi.org/10.1111/j.1750-3841.2011.02486.x

Coburn, B., Grassl, G. A., \& Finlay, B. B. (2007). Salmonella, the host and disease: a brief review. Immunology and Cell Biology, 85(2), 112-118. https://doi.org/10.1038/sj.icb.7100007

D'aoust, J.-Y., Warburton, D. W., \& Sewell, A. M. (1985). Salmonella typhimurium phage-type 10 from cheddar cheese implicated in a major Canadian foodborne outbreak. Journal of Food Protection, 48(12), 1062-1066.

Doyle, M. P., \& Buchanan, R. (Eds.). (2013). Food microbiology: fundamentals and frontiers (4th ed). Washington, DC: ASM Press.

Duncan, D. W., \& Razzell, W. E. (1972). Klebsiella Biotypes Among Coliforms Isolated from Forest Environments and Farm Produce. Applied Microbiology, 24(6), 933-938.

Estrela, C., Estrela, C. R. A., Barbin, E. L., Spanó, J. C. E., Marchesan, M. A., \& Pécora, J. D. (2002). Mechanism of action of sodium hypochlorite. Brazilian Dental Journal, 13(2), 113-117.

FAO. (2008). Good Agricultural Practices: Introduction. Retrieved April 6, 2017, from http://www.fao.org/prods/gap/index_en.htm

FAO, \& Ma. Patricia V. Azanza. (2004). Hydrogen Peroxide, Peroxyacetic Acid, Octanoic Acid, Peroxyoctanoic Acid, And 1-Hydroxyethylidene-1,1- Diphosphonic Acid (Hedp) As Components Of Antimicrobial Washing Solution. Retrieved April 30, 2017, from http://www.fao.org/fileadmin/templates/agns/pdf/jecfa/cta/63/Antimicrobials.pdf 
FAO, \& WHO (Eds.). (2003). Assuring food safety and quality: guidelines for strengthening national food control systems. Rome : [Geneva]: Food and Agriculture Organization of the United Nations ; World Health Organization.

Farber, J. M., \& Peterkin, P. I. (1991). Listeria monocytogenes, a food-borne pathogen. Microbiological Reviews, 55(3), 476-511.

Farber, J. M., Ross, W. H., \& Harwig, J. (1996). Health risk assessment of Listeria monocytogenes in Canada. International Journal of Food Microbiology, 30(1-2), 145-156.

FDA. (2001, April). Laboratory Methods - BAM: Yeasts, Molds and Mycotoxins [WebContent]. Retrieved April 3, 2017, from https://www.fda.gov/food/foodscienceresearch/laboratorymethods/ucm071435.htm

FDA-NSTA. (2009, January 17). FDA/CFSAN - Food Safety A to Z Reference Guide. Retrieved April 29, 2017, from https://web.archive.org/web/20090117202535/http://www.cfsan.fda.gov/ dms/a2z-s.html Food Poisoning Bulletin. (2012, February 3). Case Count Grows to 38 in Family Cow Campylobacter Outbreak. Retrieved April 27, 2017, from https://foodpoisoningbulletin.com/2012/case-countgrows-to-35-in-family-cow-campylobacter-outbreak/

Food Safety News. (2013, December 31). Salmonella Outbreak Linked to Cashew Cheese Sickens 15. Retrieved April 27, 2017, from http://www.foodsafetynews.com/2013/12/salmonella-outbreaklinked-to-cashew-cheese-sickens-15/

Food Safety News. (2015, September 4). Update: 9 Confirmed, 1 Probable Case in Seattle E. Coli Outbreak. Retrieved April 27, 2017, from http://www.foodsafetynews.com/2015/09/6-e-colicases-linked-to-mexican-food-sold-at-washington-farmers-markets/ 
Gardner, T. J., Fitzgerald, C., Xavier, C., Klein, R., Pruckler, J., Stroika, S., \& McLaughlin, J. B. (2011). Outbreak of Campylobacteriosis Associated With Consumption of Raw Peas. Clinical Infectious Diseases, 53(1), 26-32. https://doi.org/10.1093/cid/cir249

Garner, D., \& Kathariou, S. (2016). Fresh Produce-Associated Listeriosis Outbreaks, Sources of Concern, Teachable Moments, and Insights. Journal of Food Protection, 79(2), 337-344. https://doi.org/10.4315/0362-028X.JFP-15-387

Gaschignard, J., Levy, C., Romain, O., Cohen, R., Bingen, E., Aujard, Y., \& Boileau, P. (n.d.). Neonatal Bacterial Meningitis: 444 Cases in 7 Years. The Pediatric Infectious Disease Journal, 30(3), 212217.

Hardy Diagnostics. (2016). XLD Agar. Retrieved July 18, 2017, from https://catalog.hardydiagnostics.com/cp_prod/Content/hugo/XLDAgar.htm Harrison, J. A., Gaskin, J. W., Harrison, M. A., Cannon, J. L., Boyer, R. R., \& Zehnder, G. W. (2013). Survey of Food Safety Practices on Small to Medium-Sized Farms and in Farmers Markets. Journal of Food Protection, 76(11), 1989-1993. https://doi.org/10.4315/0362-028X.JFP-13-158

Hirsch, A., McClintock, M., \& Mocquot, G. (1952). 476. Observations on the influence of inhibitory substances produced by the lactobacilli of Gruyere cheese on the development of anaerobic spore-formers. Journal of Dairy Research, 19(02), 179.

https://doi.org/10.1017/S0022029900006427

Hitchins, A. D. (1996). Assessment of alimentary exposure to Listeria monocytogenes. International Journal of Food Microbiology, 30(1-2), 71-85.

Huang, Y., \& Chen, H. (2011). Effect of organic acids, hydrogen peroxide and mild heat on inactivation of Escherichia coli 0157:H7 on baby spinach. Food Control, 22(8), 1178-1183. https://doi.org/10.1016/j.foodcont.2011.01.012 
IFSAC. (2015). Foodborne Illness Source Attribution Estimates for Salmonella, Escherichia coli 0157 (E. coli O157), Listeria monocytogenes (Lm), and Campylobacter using Outbreak Surveillance Data. Retrieved from https://www.cdc.gov/foodsafety/pdfs/ifsac-project-report-508c.pdf

James M., J., Martin J., L., \& David A., G. (2006a). Foodborne Gastroenteritis Caused by Salmmonella and Shigella. In Mordern Food Microbiology (Seventh Edition). Springer.

James M., J., Martin J., L., \& David A., G. (2006b). Foodbrone Listeriosis. In Mordern Food Microbiology (Seventh Edition). Springer.

James M. Jay, Martin J. Loessner, \& David A. Golden. (2005). Indicators of Food Microbial Quality and Safety. In Modern Food Microbiology (pp. 473-495). Springer, Boston, MA. https://doi.org/10.1007/0-387-23413-6_20

James M. Jay, Martin J. Loessner, \& David A. Golden. (2009). Modern food microbiology (7th Edition). Springer.

Kettle, A. J., Albrett, A. M., Chapman, A. L., Dickerhof, N., Forbes, L. V., Khalilova, I., \& Turner, R. (2014). Measuring chlorine bleach in biology and medicine. Biochimica et Biophysica Acta (BBA) General Subjects, 1840(2), 781-793. https://doi.org/10.1016/j.bbagen.2013.07.004

Koseki, S., Mizuno, Y., Kawasaki, S., \& Yamamoto, K. (2011). A Survey of Iceberg Lettuce for the Presence of Salmonella, Escherichia coli O157:H7, and Listeria monocytogenes in Japan. Journal of Food Protection, 74(9), 1543-1546. https://doi.org/10.4315/0362-028X.JFP-10-424

Lambert, R. J., \& Stratford, M. (1999). Weak-acid preservatives: modelling microbial inhibition and response. Journal of Applied Microbiology, 86(1), 157-164. https://doi.org/10.1046/j.13652672.1999.00646.x

Le Minor, L., \& Popoff, M. Y. (1987). Designation of Salmonella enterica sp. nov., nom. rev., as the Type and Only Species of the Genus Salmonella: Request for an Opinion. International Journal of Systematic and Evolutionary Microbiology, 37(4), 465-468. 
Levy, D. J., Beck, N. K., Kossik, A. L., Patti, T., Meschke, J. S., Calicchia, M., \& Hellberg, R. S. (2015). Microbial safety and quality of fresh herbs from Los Angeles, Orange County and Seattle farmers' markets. Journal of the Science of Food and Agriculture, 95(13), 2641-2645. https://doi.org/10.1002/jsfa.6996

Leyer, G. J., \& Johnson, E. A. (1992). Acid adaptation promotes survival of Salmonella spp. in cheese. Applied and Environmental Microbiology, 58(6), 2075-2080.

Leyer, G. J., \& Johnson, E. A. (1997). Acid adaptation sensitizes Salmonella typhimurium to hypochlorous acid. Applied and Environmental Microbiology, 63(2), 461-467.

M. R. Adams, \& M. O. Moss. (2008). Food Microbiology (3rd Edition). Royal Society of Chemistry.

Maffei, D. F., Silveira, N. F. de A., \& Catanozi, M. da P. L. M. (2013). Microbiological quality of organic and conventional vegetables sold in Brazil. Food Control, 29(1), 226-230. https://doi.org/10.1016/j.foodcont.2012.06.013

Marriott, N. G., \& Gravani, R. B. (2006). Principles of food sanitation (5th ed). New York, N.Y: Springer. McDonnell, G., \& Russell, A. D. (1999). Antiseptics and Disinfectants: Activity, Action, and Resistance. Clinical Microbiology Reviews, 12(1), 147-179.

Minor, T. E., \& Marth, E. H. (1970). Growth of Staphylococcus aureus in acidified pasteurized milk. Journal of Milk and Food Technology, 33(11), 516-520.

Mircea Enachescu Dauthy. (1995). Fruit and vegetable processing - Contents. Retrieved May 1, 2017, from http://www.fao.org/docrep/V5030E/V5030E00.htm

Morris, J. G., \& Potter, M. E. (Eds.). (2013). Foodborne infections and intoxications (4th ed). London ; Waltham, MA: Academic.

Okike, I. O., Lamont, R. F., \& Heath, P. T. (2013). Do We Really Need to Worry About Listeria in Newborn Infants?: The Pediatric Infectious Disease Journal, 32(4), 405-406. https://doi.org/10.1097/INF.0b013e3182867fa0 
Oliveira, M. A. de, Maciel de Souza, V., Morato Bergamini, A. M., \& De Martinis, E. C. P. (2011).

Microbiological quality of ready-to-eat minimally processed vegetables consumed in Brazil. Food Control, 22(8), 1400-1403. https://doi.org/10.1016/j.foodcont.2011.02.020

Omar A. Oyarzabal, \& Steffen Backert. (2011). Microbial Food Safety: An Introduction. Springer.

Padel, S., \& Foster, C. (2005). Exploring the gap between attitudes and behaviour: Understanding why consumers buy or do not buy organic food. British Food Journal, 107(8), 606-625. https://doi.org/10.1108/00070700510611002

Painter, J. A., Hoekstra, R. M., Ayers, T., Tauxe, R. V., Braden, C. R., Angulo, F. J., \& Griffin, P. M. (2013). Attribution of Foodborne Illnesses, Hospitalizations, and Deaths to Food Commodities by using Outbreak Data, United States, 1998-2008. Emerging Infectious Diseases, 19(3), 407-415. https://doi.org/10.3201/eid1903.111866

Pao, S., Kalantari, A., \& Huang, G. (2006). Utilizing Acidic Sprays for Eliminating Salmonella enterica on Raw Almonds. Journal of Food Science, 71(1), M14-M19. https://doi.org/10.1111/j.13652621.2006.tb12394.x

Parish, M. e., Beuchat, L. r., Suslow, T. v., Harris, L. j., Garrett, E. h., Farber, J. n., \& Busta, F. f. (2003). Methods to Reduce/Eliminate Pathogens from Fresh and Fresh-Cut Produce. Comprehensive Reviews in Food Science and Food Safety, 2, 161-173. https://doi.org/10.1111/j.15414337.2003.tb00033.x

Park, S.-H., Choi, M.-R., Park, J.-W., Park, K.-H., Chung, M.-S., Ryu, S., \& Kang, D.-H. (2011). Use of Organic Acids to Inactivate Escherichia coli O157:H7, Salmonella Typhimurium, and Listeria monocytogenes on Organic Fresh Apples and Lettuce. Journal of Food Science, 76(6), M293M298. https://doi.org/10.1111/j.1750-3841.2011.02205.x

Peter Feng, Stephen D. Weagant, Michael A. Grant, \& William Burkhardt. (2013). Laboratory Methods BAM: Enumeration of Escherichia coli and the Coliform Bacteria [WebContent]. Retrieved April 
9, 2017, from

https://www.fda.gov/Food/FoodScienceResearch/LaboratoryMethods/ucm064948.htm

Peters, C., Hansen, E., Clingerman, J., Hereford, A., \& Askins, N. (2012, September 24). West Virginia Food System Opportunities and constraints in local food supply chains. Retrieved from http://www.downstreamstrategies.com/documents/reports_publication/DS_wv_food_system_ opportuities_and_constraints_in_local_food_supply_chains.pdf

Rice, A. C., \& Pederson, C. S. (1954). Chromatographic Analysis Of Organic Acids In Canned Tomato Juice, Including The Identification Of Pyrrolidonecarboxylic Acid. Journal of Food Science, 19(1-6), 106-114. https://doi.org/10.1111/j.1365-2621.1954.tb17428.x

RJ Gilbert, J de Louvois, T Donovan, C Little, K Nye, CD Ribeiro, ... FJ Bolton. (2000). Guidelines for the microbiological quality of some ready-to-eat foods sampled at the point of sale. Communicable Disease and Public Health, (3: 163-7). Retrieved from http://mb-labs.com/wpcontent/uploads/2014/08/Micro-Limits-Ready-to-Eat-Foods.pdf

Robert L. Scharff. (2010, March 8). Foodborne Illness By The Numbers. Retrieved April 1, 2017, from http://www.foodsafetynews.com/2010/03/foodborne-illness-by-the-numbers/

Scallan, E., Hoekstra, R. M., Angulo, F. J., Tauxe, R. V., Widdowson, M.-A., Roy, S. L., ... Griffin, P. M. (2011). Foodborne Illness Acquired in the United States-Major Pathogens. Emerging Infectious Diseases, 17(1), 7-15. https://doi.org/10.3201/eid1701.P11101

Scheinberg, J. A., Dudley, E. G., Campbell, J., Roberts, B., DiMarzio, M., DebRoy, C., \& Cutter, C. N. (2017). Prevalence and Phylogenetic Characterization of Escherichia coli and Hygiene Indicator Bacteria Isolated from Leafy Green Produce, Beef, and Pork Obtained from Farmers' Markets in Pennsylvania. Journal of Food Protection, 80(2), 237-244. https://doi.org/10.4315/0362028X.JFP-16-282 
Schlech, W. F. I., Lavigne, P. M., Bortolussi, R. A., Allen, A. C., Haldane, E. V., Wort, A. J., ... Broome, C. V. (1983). Epidemic Listeriosis - Evidence for Transmission by Food. New England Journal of Medicine, 308(4), 203-206. https://doi.org/10.1056/NEJM198301273080407

Schuchat, A., Swaminathan, B., \& Broome, C. V. (1991). Epidemiology of human listeriosis. Clinical Microbiology Reviews, 4(2), 169-183.

Serhan Sakarya, Cengiz Gokt “ urk, Turgut O” zturk, \& M. Bulent Ertugrul. (2010). Sialic acid is required for nonspecific adherence of Salmonella enterica ssp. enterica serovar Typhi on Caco-2 cells. FEMS Immunology \& Medical Microbiology, 58(3), 330-335. https://doi.org/10.1111/j.1574$695 X .2010 .00650 . x$

Shen, C., Luo, Y., Nou, X., Wang, Q., \& Millner, P. (2013). Dynamic Effects of Free Chlorine Concentration, Organic Load, and Exposure Time on the Inactivation of Salmonella, Escherichia coli O157:H7, and Non-0157 Shiga Toxin-Producing E. coli. Journal of Food Protection, 76(3), 386-393. https://doi.org/10.4315/0362-028X.JFP-12-320

Su, L., \& Chiu, C. (2007). Salmonella: clinical importance and evolution of nomenclature. Chang Gung Medical Journal, 30(3), 210.

Theron, M. M., \& Lues, J. F. R. (2011). Organic acids and food preservation. Boca Raton: CRC Press, Taylor \& Francis Group.

Topè, A. M., Rogers, P. F., \& Hitter, A. C. (2014). Evaluation of Good Agricultural Practices (GAP) Compliance by Small Farmers in Kentucky: Assessing Microbial Quality of Produce. Journal of Agriculture and Environmental Sciences, 3(4). https://doi.org/10.15640/jaes.v3n4a3

U.S. FDA. (1998). Guidance for Industry: Guide to Minimize Microbial Food Safety Hazards for Fresh Fruits and Vegetables [WebContent]. Retrieved April 6, 2017, from https://www.fda.gov/RegulatoryInformation/Guidances/ucm064574.htm 
U.S. FDA. (2004, January 23). U.S. DEPARTMENT OF HEALTH AND HUMAN SERVICES FOOD AND DRUG ADMINISTRATION ) ) Amending 21 C.F.R. Part 109 ) to Establish a Reg. Retrieved June 22, 2017, from

https://google2.fda.gov/search?q=cache:XRN_9azhVhcJ:www.fda.gov/ohrms/dockets/dailys/03 /dec03/122403/03p-0574-cp00001-02-

vol1.pdf+zero+tolerance+listeria\&client=FDAgov\&site=FDAgov\&lr=\&proxystylesheet=FDAgov\&o utput=xml_no_dtd\&ie=UTF-8\&access=p\&oe=UTF-8

U.S. FDA. (2011). 40 CFR 180.1196 - Peroxyacetic acid; exemption from the requirement of a tolerance. Retrieved May 1, 2017, from https://www.law.cornell.edu/cfr/text/40/180.1196

U.S. FDA. (2014a). Laboratory Methods - BAM: Salmonella [WebContent]. Retrieved July 15, 2017, from https://www.fda.gov/food/foodscienceresearch/laboratorymethods/ucm070149.htm

U.S. FDA. (2014b). Science \& Research (Food) - Chapter V. Methods to Reduce/Eliminate Pathogens from Produce and Fresh-Cut Produce [WebContent]. Retrieved July 6, 2017, from https://www.fda.gov/Food/FoodScienceResearch/ucm091363.htm

U.S. FDA. (2016). Sec. 173.315 Chemicals used in washing or to assist in the peeling of fruits and vegetables. Retrieved April 30, 2017, from https://www.accessdata.fda.gov/SCRIPTs/cdrh/cfdocs/cfcfr/CFRSearch.cfm?fr=173.315\&Search Term=chemicals

USDA-AMS. (2015a). Hypochlorous Acid TR 0813 15.pdf. Retrieved from https://www.ams.usda.gov/sites/default/files/media/Hypochlorous\%20Acid\%20TR\%2008\%201 3\%2015.pdf

USDA-AMS. (2015b, July 24). 2014 Farmers Market Managers Survey Summary Report. Retrieved May 27,2017 , from 
https://www.ams.usda.gov/sites/default/files/media/2014\%20Farmers\%20Market\%20Manager s\%20Survey\%20Summary\%20Report\%20final\%20July\%2024\%202015.pdf

USDA-AMS. (2016). Peracetic Acid Handling/Processing. Retrieved from https://www.ams.usda.gov/sites/default/files/media/Peracetic\%20Acid\%20TR\%203_3_2016\%2 OLivestock.pdf

USDA-AMS. (2017a). Good Agricultural Practices (GAP) \& Good Handling Practices (GHP) | Agricultural Marketing Service. Retrieved April 3, 2017, from https://www.ams.usda.gov/services/auditing/gap-ghp

USDA-AMS. (2017b, June). Local Food Directories: National Farmers Market Directory. Retrieved May 27, 2017, from https://www.ams.usda.gov/local-food-directories/farmersmarkets USFDA. (2016). Consumers - Foodborne Illnesses: What You Need to Know [WebContent]. Retrieved May 22, 2017, from https://www.fda.gov/food/resourcesforyou/consumers/ucm103263.htm Wood, J. L., Chen, J. C., Friesen, E., Delaquis, P., \& Allen, K. J. (2015). Microbiological Survey of Locally Grown Lettuce Sold at Farmers' Markets in Vancouver, British Columbia. Journal of Food Protection, 78(1), 203-208. https://doi.org/10.4315/0362-028X.JFP-14-199

Yeni, F., Acar, S., Polat, Ö. G., Soyer, Y., \& Alpas, H. (2014). Rapid and standardized methods for detection of foodborne pathogens and mycotoxins on fresh produce. Food Control, 40, 359-367. https://doi.org/10.1016/j.foodcont.2013.12.020

Zhu, Q., Gooneratne, R., \& Hussain, M. (2017). Listeria monocytogenes in Fresh Produce: Outbreaks, Prevalence and Contamination Levels. Foods, 6(3), 21. https://doi.org/10.3390/foods6030021 Zhu, Q., \& Hussain, M. A. (2015). Prevalence of Listeria species in Fresh Salad Vegetables and Ready-toEat Foods Containing Fresh Produce Marketed in Canterbury, New Zealand. Advanced in Food Technology and Nutritional Sciences - Open Journal, 1(1), 5-9. https://doi.org/10.17140/AFTNSOJ-1-102 


\section{Ch. 2 Figures}

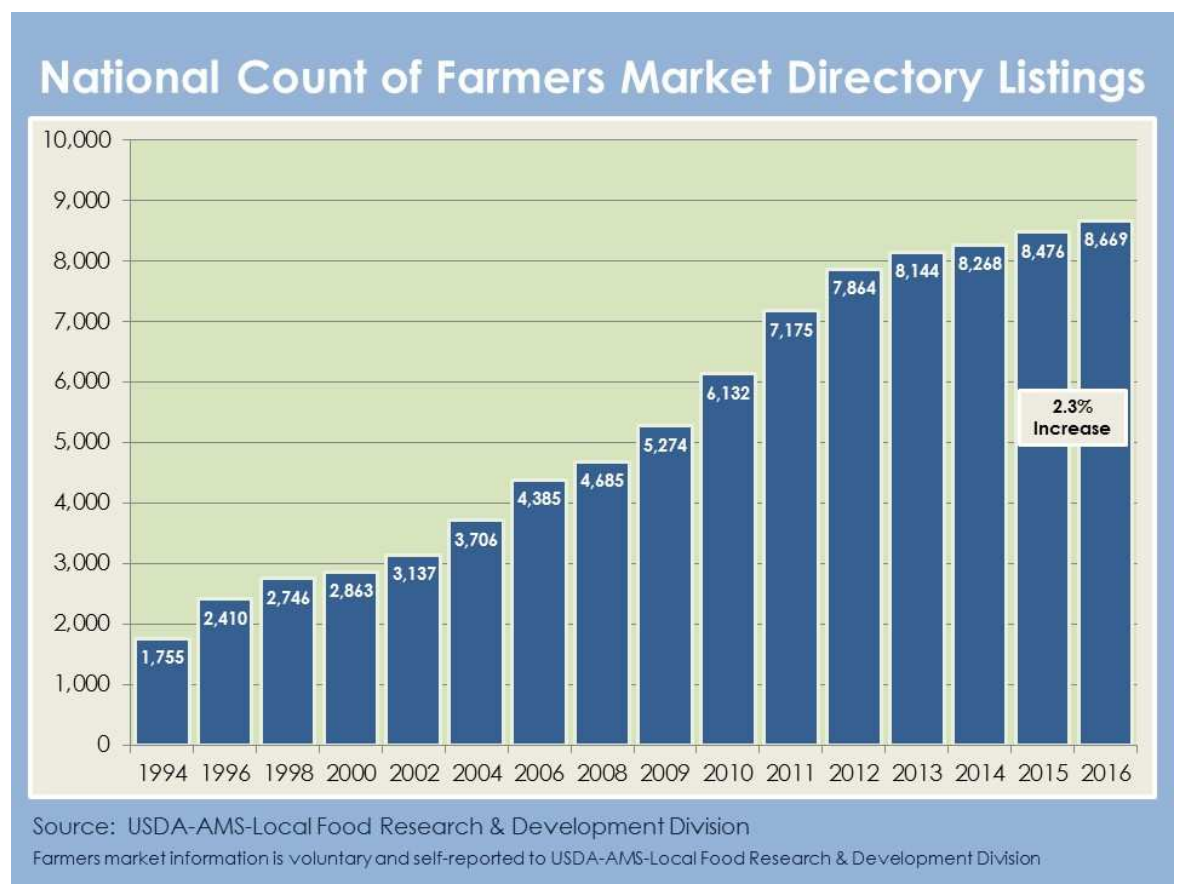

Figure 1. National count of operating farmers' markets in USA from 1994 to 2016 (Copied from USDA-AMS, 2016b)

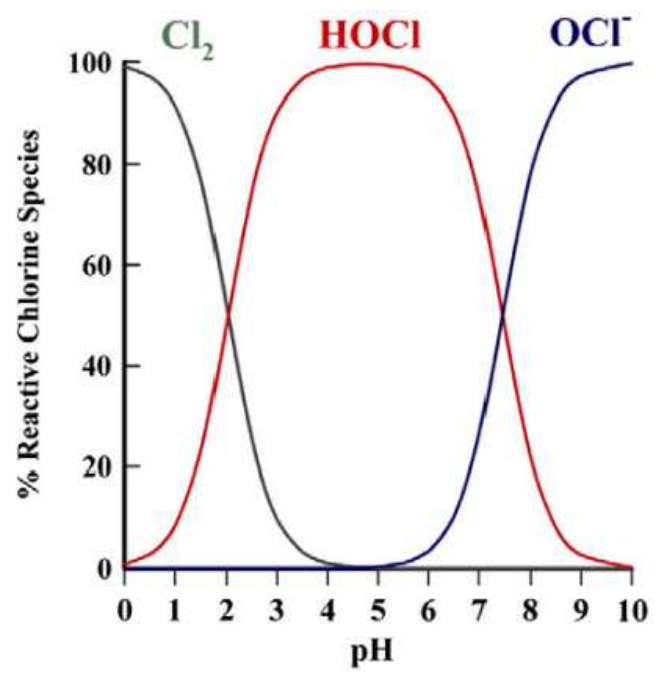

Figure 2. pH profile for reactive chlorine species, copied from Kettle et al, 2014 (Copied from Kettle et al., 2014). 


\title{
CHAPTER 3
}

\section{Microbiological Quality and Safety of Fresh Produce in West Virginia and Kentucky Farmers' markets}

\begin{abstract}
Microbiological quality/safety of fresh produce from farmers' markets (FM) were evaluated to assess post-harvest washing with antimicrobials to inactivate Salmonella and Listeria monocytogenes on fresh produce. In study I, 212 produce samples were tested for the presence of Salmonella and Listeria spp. using modified FDA-BAM methods. Aerobic plate counts (APCs), total coliforms (TCCs), and yeast/molds were analyzed on petri-films. Among the 212 samples, range of detection for APCs, TCCs, and yeast/molds was 3.72-5.63, 3.67-5.47, and 3.07-4.13 $\log \mathrm{CFU} / \mathrm{g}$, respectively, with spinach containing the highest $(P<0.05)$ populations. Across all tested samples, Salmonella enterica spp. enterica was detected on $18.6 \%$ of spinach, $10.9 \%$ of tomatoes, $18.5 \%$ of peppers, and $56.3 \%$ of cantaloupes, which is much higher than previous reported. Only $3.78 \%$ of the samples were confirmed for Listeria spp., and $50 \%$ of these isolates were identified as L. monocytogenes, based on multiplex PCR results.
\end{abstract}

Keywords: Microbiological quality, Salmonella, Listeria monocytogenes, fresh produce, farmers' markets. 


\section{Introduction}

Farmers' markets are a very important agriculture business in West Virginia, creating an average annual revenue of $\$ 41,200$ for full time produce farmers and approximately $\$ 20,000$ for part time farmers (internal unpublished data).

Morgantown, the second largest city in WV, has 6 farmers' markets open from Monday to Saturday. The Morgantown, WV farmers' markets contain 5 to 35 vendors with half of their total gross sales generated from vegetables and fruits.

In Kentucky, there are more than 159 farmers' markets across the state (KY Department of Agriculture, 2016). Bowling Green, the third largest city in KY, has three farmers' markets that are open Tuesday and Saturday. The Bowling Green, KY markets have approximately 100 vendors with $45 \%$ of them selling fresh produce. Our recent Good Agriculture Practices (GAP) survey of 160 small-scale produce growers in 21 counties across KY indicated that $90 \%$ of the growers are familiar with GAPs, but 1.) only $47 \%$ opted to practice water quality GAPs and 2.) only $55 \%$ chose to observe soil amendment GAPs. Participants also failed to identify many sources of potential microbiological contamination including soil, ice, and cooling and refrigeration (only $28-41 \%$ recognition, Vincent et al., 2015). Therefore, to reduce food safety risks associated with produce at farmers' markets from food safety risks, it is important to assess and understand the risks of contamination during handling. Furthermore, no information is currently available regarding the presence of pathogens on produce that is sold at $\mathrm{WV}$ and $\mathrm{KY}$ farmers' markets.

The new Food Safety Modernization Act (FSMA)-Produce Safety Rule was proposed in 2013 and became effective in 2015 to improve fresh produce safety in participating states (U.S. FDA, 2015). Small produce farms are exempted from the FSMA if farms 1 .) sold $\leq \$ 25,000$ 
average annual produce during the previous three-year period; 2.) averaged $<\$ 500,000$ in food sales annually (for the last 3 years); and 3.) sell most of their food directly to consumers, restaurants and stores within the state or 275 miles or less of the farm (U.S. FDA, 2015). However, a farm with a qualified FSMA exemption is still required to have their information (name, address, place of produce grown) on the product label. Although FSMA allows flexibility for local, small produce growers, the exemption can be withdrawn if their products have food safety problems or their farms directly linked to an outbreak as determined by FDA (U.S. FDA, 2015).

This study evaluated the prevalence of Salmonella enterica spp. enterica and Listeria spp.and enumerated the populations of aerobic organisms(aerobic plate counts; APCs), coliforms and yeast/molds on fresh produce obtained from farmers' markets in Morgantown, WV and Bowling Green, KY. 


\section{Materials and Methods}

\subsection{Fresh produce sample collection and preparation}

Our experimental protocol called for a total of approximately 200 samples selected from 4 or 5 fresh produce commodities from at least 5 vendors of each commodity. In total, 212 fresh produce samples of tomato (64 samples, 13 vendors, 4-6 each), green pepper (54 samples, 11 vendors, 4-6 each), cucumber (35 samples, 5 vendors, 6-8 each), cantaloupe (16 samples, 12 from one vendor, 4 from another vendor) and spinach (43 samples, 8 vendors, 5-7 each) were collected. Samples were aseptically collected from a total of 39 vendors from two farmers' markets in Morgantown, West Virginia, and one farmers' market in Bowling Green, Kentucky. Tomato, green pepper, cucumber and spinach are the four most popular produce commodities in farmers' market in the fall. Cantaloupes were also collected due to the recent $2011 \mathrm{~L}$. monocytogenes outbreak (CDC, 2011); only one vendor was selling this commodity in each city.

Morgantown is the second largest city in WV and the location of West Virginia University (WVU). Sample collocation was coordinated with the Morgantown Farmers' market Association and WV Small Farm Center. Bowling Green is the third largest city in KY and the

location of Western Kentucky University (WKU, our research collaborator). Sample collection in Bowling Green farmers' market was coordinated with Dr. Martin Stone of WKU. Produce sample collection and microbial pathogen analysis was approved by the WVU biosafety committee (IRB/IBC\#15-04-07). Vendors were aware of the purpose for these sample collections, and some operators were interested in obtaining the test results. All collected produce samples were brought at their listed market price and selected by our research team members. 
Produce samples were collected on Wednesday afternoons from 1:00 to 4:00 PM or Saturday mornings from 8:00 to 12:00 PM between August and November 2015. Each farmers' market was visited two to four times based on the sample availability. Each individual produce sample was transferred into a separate plastic bag to avoid cross contamination. Following sample collection, fresh produce was transported (Morgantown farmers' markets) in a cooler with ice or shipped overnight (Bowling Green farmers' market) in boxes containing ice-packs to the food microbiology laboratory at WVU. Upon receipt, samples were immediately stored at refrigerated temperature $\left(4-5^{\circ} \mathrm{C}\right)$. All produce samples were processed within $12-24 \mathrm{~h}$ of collection following microbial analysis procedure described below.

The fresh produce sample was prepared was using a modified FDA-BAM method (U.S. FDA, 2014b). Spinach samples were prepared by mixing a 25-g portion with $225 \mathrm{~mL}$ of buffered peptone water (BPW; Becton Dickinson and Company, Sparks, MD, USA) in a sterile WhirlPak ${ }^{\circledR}$ bag (Whirl-Pak, Nasco, Modesto, CA, USA) and homogenized (Masticator, IUL Instruments, Barcelona, Spain) for $2 \mathrm{~min}$. Each individual tomato, green pepper and cucumber was aseptically placed in a sterile Whirl-Pak ${ }^{@}$ bag containing 200 mL of BPW and shaken manually vertically 60 times, followed by massaging for $60 \mathrm{sec}$ to detach bacterial cells (Gereffi, Sreedharan, \& Schneider, 2015). Each cantaloupe was rinsed in $800 \mathrm{~mL}$ of BPW and vigorously shaken for $60 \mathrm{sec}$ in a sterile chicken-rinse bag (Nasco, Fort Atkinson, WI, USA) (USDA- FSIS, 2016). The BPW from each sample was considered a "fresh produce rinse" and assumed to represent pathogens present on food surfaces. 


\subsection{APCs, total coliform and yeast/molds testing of fresh produce}

Fresh produce rinses (tomato, green pepper, cucumber, and cantaloupe) or homogenizer rinse (spinach) were ten-fold serially diluted in $0.1 \% \mathrm{BPW}$, followed by surface-plating onto $3 \mathrm{M}^{\mathrm{TM}}$ APCs, coliforms, and yeast/molds petrifilm (3M Microbiology Products, St. Paul, MN, USA) for enumeration of the total aerobic bacteria, coliform, and fungi populations, respectively, in accordance with manufacturer instructions. Petrifilms were manually counted after incubation at $35^{\circ} \mathrm{C}$ for $72 \mathrm{~h}$ (APCs), $35^{\circ} \mathrm{C}$ for $48 \mathrm{~h}$ (coliform) and $25^{\circ} \mathrm{C}$ for $120 \mathrm{~h}$ (yeast $/ \mathrm{molds}$ ).

\subsection{Isolation of Salmonella and Listeria spp.}

The isolation and identification of Salmonella enterica spp. enterica (U.S. FDA, 2014a) and Listeria spp. (U.S. FDA, 2016a) were accomplished with modified FDA-BAM methods, and verified in preliminary studies with artificially inoculated produce samples. Fresh produce BPW rinse solutions, after testing for APCs, coliforms, and yeast $/$ molds, were incubated at $35^{\circ} \mathrm{C}$ for $24 \mathrm{~h}$ for pre-enrichment. For isolation of Salmonella enterica spp. enterica, $0.1 \mathrm{~mL}$ of each pre-enriched solution was enriched in $10 \mathrm{~mL}$ of Rappaport Vassiliadis (RV, Hardy Diagnostics, MD, USA), followed by incubation at $42^{\circ} \mathrm{C}$ for $24 \mathrm{~h}$. Following incubation, a loopful of enriched RV solution was streaked onto xylose lysine deoxycholate (XLD) agar and incubated at $35{ }^{\circ} \mathrm{C}$ for $24 \mathrm{~h}$. After incubation, 1 to 3 presumptive Salmonella colonies from XLD agar (red colony with black center) were confirmed using an Oxoid Salmonella Latex Agglutination Test Kit (Oxoid Ltd, Basingstoke, Hampshire, UK) followed by API 20E test kits (bioMẻrieux, Durham, NC, USA). If inconsistent results were obtained between latex and API 20E tests, the final results were confirmed by the molecular test described below. To test for Listeria spp., $1.0 \mathrm{~mL}$ of the pre-enriched BPW rinse solution was transferred into $10 \mathrm{~mL}$ of UVM broth (Becton 
Dickinson and Company, Sparks, MD, USA), incubated at $35^{\circ} \mathrm{C}$ for $48 \mathrm{~h}$, and streaked onto Modified-Oxford agar (MOX, Becton Dickinson and Company, Sparks, MD, USA). One to three presumptive Listeria colonies (black color) were confirmed using the catalase test on glass slides where a positive test generated a bubble after reacting with $\mathrm{H}_{2} \mathrm{O}_{2}$ reagent ( $3 \%$, Hardy Diagnostics, MD, USA), and the Listeria12L-kit (Oxoid ${ }^{\mathrm{TM}}$, Remel Inc., Lenexa, KS, USA). Biochemically confirmed Salmonella and Listeria isolates were grown in tryptic soy broth at $35^{\circ} \mathrm{C}$ for $24 \mathrm{~h}$ and stored in a refrigerator until DNA extraction for molecular identification.

\subsection{Molecular identification of Salmonella and Listeria spp.}

Nucleic acids were extracted from a 5-mL culture grown in tryptic soy broth. Specifically, cells from $1.5 \mathrm{~mL}$ of culture were concentrated via centrifugation at $10,000 \times \mathrm{g}$ for 5 minutes at $4{ }^{\circ} \mathrm{C}$ into Matrix E lysing tubes (MP Biomedical, Santa Ana, CA, USA). The supernatant was removed, and the cell debris was retained. An additional $1.5 \mathrm{~mL}$ of culture was added to the same Matrix E lysing tube and centrifuged to concentrate the cells in the tube. This concentration method was repeated to reach a total volume of $5 \mathrm{~mL}$. DNA was extracted from the concentrated cell pellet using previously published methods (Griffiths, Whiteley, O'Donnell, \& Bailey, 2000).

Quantitative polymerase chain reaction (qPCR) was used to determine the presence/absence of the invasion protein (invA) of Salmonella enterica subsp. enterica (Lee, Shannon, \& Beaudette, 2006). Each $25-\mu 1$ qPCR reaction consisted of $1 \mathrm{X}$ of TaqMan ${ }^{\circledR}$ Fast Advanced Master Mix (Applied Biosystems, Foster, CA, USA), previously published optimal primer (Integrated DNA Technologies, Inc., Coralville, IA, USA), probe concentrations (Biosearch Technologies, Inc., Novato, CA, USA), template DNA (1 to $2.5 \mathrm{ul}$ ), and molecular 
grade water (Ambion, Carlsbad, CA, USA). Amplification of the invA gene was performed on a 7300 Real-Time PCR system (Applied Biosystems) according to previously published methods (Lee et al., 2006). Control samples for each qPCR and PCR reaction included negative controls (i.e., DNA-free water as the template), positive controls (e.g., linear DNA from pure cultures) and matrix-spiked samples (i.e., linear DNA from pure cultures added to the DNA template) to

test for sample reaction inhibition. S. Typhimurium ATCC 14028 was used as a positive control.

Multiplex PCR was used to determine the presence or absence of the $1 m o 1118$, Imo0737, ORF2110 and ORF 2819 genes of L. monocytogenes as well as the prs gene of Listeria spp. using previously published methods (Doumith, Buchrieser, Glaser, Jacquet, \& Martin, 2004). Each 25- $\mu 1$ reaction consisted of 1X AmpliTaq Gold ${ }^{\circledR} 360$ PCR mastermix (Fisher Scientific, Pittsburgh, PA, USA), previously published primer concentrations (Integrated DNA Technologies, Inc.,), molecular biology grade water (Ambion) and DNA template (1 ul). Listeria spp. PCR products were visualized by gel electrophoresis with ethidium bromide (Fisher Scientific, Fair Lawn, NJ, USA) staining. The L. monocytogenes strains L502 (chocolate milk outbreak serotype 1/2b), L2624 and L2625 (cantaloupe outbreak serotype 1/2b), supplied by Dr. Joshua Gurtler from USDA-ARS, Wyndmoor, PA, were used as positive controls.

\subsection{Data analysis}

To compare the differences in the percent Salmonella and Listeria spp. Positive samples between Morgantown and Bowling Green farmers' market, a Z-test from Minitab (https://onlinecourses.science.psu.edu/stat500/node/55) was performed at a significance level at 0.05 . For 0 percentage results, " $0.1 \%$ " was entered in the software to complete data analysis. Bacterial counts were converted to $\log$ CFU/g of APCs, TCCs, yeast/molds, Salmonella and $L$. 
monocytogenes were analyzed using the One-Way ANOVA Procedure of SAS (version 9.2, SAS Institute, Cary, NC). Each type of produce samples' analysis was repeated two to four times to compare the APCs, coliforms and yeast/molds in various fresh produce. 


\section{Results and Discussion}

\subsection{APCs, coliforms, and yeast/molds results}

APC counts were used as hygiene indicators to evaluate microbial quality and shelf-life of fresh produce sold at farmers' markets. These counts ranged from 3.7 to $5.6 \log \mathrm{CFU} / \mathrm{g}$ among five different fresh produce types (Table 1). Spinach samples (leafy greens) had higher APCs $(P<0.05,5.6 \log \mathrm{CFU} / \mathrm{g})$ than the other four produce commodities (post hoc Tukey HSD) (Table 1). A recent study of lettuce from a farmers' market in Vancouver, British Columbia, Canada, found that APCs ranged from 4.8 to $7.8 \log$ CFU/g (Wood et al., 2015).

Coliforms are widely distributed in nature and are commonly found on raw vegetables. Similar APCs, the coliform counts of the five fresh produce types ranged from 3.8 to $5.4 \mathrm{log}$ CFU/g, with the highest population of $5.4 \log$ CFU/g associated with spinach (Table 1). Spinach coliform counts were higher compared to previously reported studies on leafy greens. Specifically, others have reported that $3.15 \log$ CFU/g was found on parsley, $2.66 \log$ CFU/g was found on cilantro, and 1.60 to $2.20 \log \mathrm{CFU} / \mathrm{g}$ was found on lettuce from farmers' markets in Los Angeles and Seattle, U.S. (Levy et al., 2015), and Vancouver, British Columbia, Canada (Wood et al., 2015). Yeast and molds were less than those of the APC and coliforms counts, ranging from 3.2 to $4.1 \log \mathrm{CFU} / \mathrm{g}$. Again, the highest $(P<0.05)$ counts of yeast and molds were found on spinach. Overall, APC, coliform, and yeast and mold counts suggest that farmers' market, produce vendors may need to apply post-harvest control process to reduce the level of background flora on produce surfaces. 


\subsection{Salmonella spp. and Listeria spp. prevalence}

A total of 212 fresh produce samples of tomato, pepper, cucumber, cantaloupe and spinach were evaluated for Salmonella enterica spp. enterica and Listeria spp. Presumptive Salmonella colonies, based on API 20E strips with a biochemical profile of 6704752 (Levy et al., 2015), were further confirmed by testing for the invA gene by real-time qPCR. For Listeria spp., the samples that tested positive using Listeria12L biochemistry kit were confirmed by multiplex PCR to determine whether they were L. monocytogenes. The biochemistry test results were in complete agreement with the molecular confirmation tests for Salmonella enterica spp. enterica and Listeria spp. positive samples.

Overall frequency of Salmonella enterica spp. enterica detection on fresh produce was $16.03 \%(34 / 212)$. Salmonella was detected on $10.9 \%(7 / 64)$ of tomatoes, $18.5 \%(10 / 54)$ of peppers, $56.3 \%(9 / 16)$ of cantaloupes, and $18.6 \%$ (8/43) of spinach (Table 2). However, this study did not find any Salmonella on a total of 35 cucumbers (Table 2). Only cucumbers from the Morgantown farmers' market were tested for Salmonella enterica spp. enterica because cucumbers were out of season at the Bowling Green farmer's market. The percentages of tomatoes, peppers and cantaloupe samples containing Salmonella from Bowling Green was significantly higher $(P<0.05)$ than those from the Morgantown farmers' market (Table 2). The prevalence of Salmonella found in this study was much greater than the levels reported most recently for Salmonella from fresh produce sold at farmers' markets in the U.S (Leang, 2013; Levy et al., 2015). Leang (2013) reported that no Salmonella was detected in a total of 63 lettuce and 63 tomatoes sold at 5 farmers' markets in the city of Seattle, WA. Levy et al. (2015) reported that only 1 of 133 fresh herbs (basil, cilantro, and parsley) from Los Angeles and Seattle farmers' markets contained Salmonella spp. The occurrence of Salmonella on locally grown produce may 
be attributed to the variance of produce field management, lack of regulatory guidance, emphasis on minimal antimicrobial application, and interests in using organic processes. Results of this study indicate a high possibility of Salmonella contamination of fresh produce sold at the Morgantown and Bowling Green farmers' markets. Furthermore, these results illustrate a need for additional investigations in fresh produce from farmers' markets.

Since the 2012 Listeria outbreak associated with cantaloupes, the presence of Listeria spp., especially L. monocytogenes, on fresh produce has become a major concern (CDC, 2011). There was only one vendor that sold cantaloupes at each of the Morgantown and Bowling Green farmers' markets. Listeria spp. was isolated from 8 of $212(3.8 \%)$ fresh produce samples, including 1 tomato, 3 green peppers, 2 cucumbers and 2 cantaloupes (Table 3 ). Recent study conducted by Scheinberg et al. (2017) among 58 vendors in 25 farmers' market across the state of Pennsylvania also reported 3.9\% (6/152) of fresh produce samples were positive for Listeria spp., which includes $2 \%(1 / 54)$ of kale samples, $4 \%$ ( 2 of 52$)$ of lettuce samples, and $7 \%$ (3 of 46) of spinach samples. In our study, the majority (6) of Listeria positive samples were from the Morgantown farmers' market; Although 2 positive pepper samples were from the Bowling Green farmers' market (Table 3). Among those Listeria spp. isolates, L. monocytogenes was most prevalent (50\%), including 1 tomato, 2 cucumbers and 1 cantaloupe sample; possible serovars were $1 / 2 b, 3 b, 4 b, 4 d$ and $4 e$ based on the multiplex PCR results (data not shown). However, the same study of Scheinberg et al. (2017) detected only $0.65 \%$ (1 of 152) of total produce samples was identified as L. monocytogenes. The presence of Listeria spp. on fresh produce is also reported in an early study of Heisick et al. (1989), which found that $1.1-33.2 \%$ of fresh produce sold at a Minnesota supermarket were positive for Listeria spp. L. monocytogenes was the dominate species on potatoes $(25.8 \%)$ and radishes $(30.3 \%)$. A recent study conducted at a small 
scale, local mushroom facility in Pennsylvania found $29(15.8 \%)$ samples that were positive for Listeria spp., and $1.6 \%$ of the Listeria spp. isolates were confirmed as L. monocytogenes (Viswanath et al., 2013). Only $0.65 \%$ (1/152) was identified as L. monocytogenes. According to U.S.-FDA, the presence of contaminated water on the floors of packing and storage rooms, poorly cleaned or sanitized food contact surfaces, and unregulated traffic patterns can be primary sources of L. monocytogenes contamination on fresh produce (U.S. FDA, 2011b). Our findings will help to fill gaps in knowledge regarding the occurrence of Listeria spp. and $L$. monocytogenes on locally grown fresh produce and will be useful for both state agriculture and public health departments. Furthermore, these studies can assist risk assessments of foodborne outbreaks caused by Listeria spp.

Due to budgetary restraints, only a limited sample size of fresh produce from Morgantown and Bowling Green farmers' market were tested for Salmonella and Listeria spp. Therefore, results may not accurately reflect the food safety situation of farmers' markets in the entire WV and KY area. However, the frequency of pathogens detected on fresh produce reported herein are higher than the range reported from other farmers' markets nationwide. Therefore, an emphasis on the importance of Good Agriculture Practices (GAP) from pre- to post-harvest and merchandizing of locally grown fresh produce in WV and KY area is needed. Furthermore, these results suggest that a campaign to inform vendors of the potential risk of produce contamination by foodborne pathogens is warranted. In 2015, WV and KY joined in the Produce Safety Alliance (PSA) led by Cornell University; prior to this study, there were no intensive, GAP training programs for farmers' market personnel. A limited number of farmers' market growers were GAP certified in either state. Our results suggest that developing and organizing more GAP training courses and validating post-harvest control strategies, such as 
applying washing steps during fresh produce processing, are important. In addition, coordination and collaboration between university extension services and state agriculture departments in these two states is warranted. An initial GAP and FSMA training course was offered in Feb 2017 for extension agents and small produce growers from $\mathrm{WV}$ and $\mathrm{KY}$ coordinated by $\mathrm{WV}$ Department of Agriculture and WVU extension.

The higher levels of Salmonella and L. monocytogenes found this study than levels reported by others (Amy Leang, 2013; Levy et al., 2015) could be attributed to the lack of postharvest pathogen control process. Small produce growers must be convinced to support the application of antimicrobials in their post-harvest process system, either through scientific literature, agricultural extension bulletins or other training efforts. Therefore, the antimicrobial data presented in this study may be used to provide preliminary information for efficacy of antimicrobials used during produce washing process for locally small growers.

In conclusion, this study demonstrates that Salmonella and Listeria are present on select fresh produce sold at WV and KY local farmers' markets. Our data indicate a need for vendors selling fresh produce at farmers' markets, to improve the microbial safety of their produce. 


\section{References}

Amy Leang. (2013). Prevalence of Salmonella and E. coli on Produce from Seattle Farmers Markets. University of Washington. Retrieved from https://digital.lib.washington.edu/researchworks/bitstream/handle/1773/23403/Leang_washin gton_02500_11796.pdf?sequence=1\&isAllowed=y

CDC. (2011). Multistate Outbreak of Listeriosis Associated with Jensen Farms Cantaloupe --- United States, August--September 2011. Retrieved May 10, 2017, from https://www.cdc.gov/mmwr/preview/mmwrhtml/mm6039a5.htm

Doumith, M., Buchrieser, C., Glaser, P., Jacquet, C., \& Martin, P. (2004). Differentiation of the Major Listeria monocytogenes Serovars by Multiplex PCR. Journal of Clinical Microbiology, 42(8), 38193822. https://doi.org/10.1128/JCM.42.8.3819-3822.2004

Gereffi, S., Sreedharan, A., \& Schneider, K. R. (2015). Control of Salmonella Cross-Contamination between Green Round Tomatoes in a Model Flume System. Journal of Food Protection, 78(7), 1280-1287. https://doi.org/10.4315/0362-028X.JFP-14-524

Griffiths, R. I., Whiteley, A. S., O’Donnell, A. G., \& Bailey, M. J. (2000). Rapid Method for Coextraction of DNA and RNA from Natural Environments for Analysis of Ribosomal DNA- and rRNA-Based Microbial Community Composition. Applied and Environmental Microbiology, 66(12), 54885491.

Heisick, J. E., Wagner, D. E., Nierman, M. L., \& Peeler, J. T. (1989). Listeria spp. found on fresh market produce. Applied and Environmental Microbiology, 55(8), 1925-1927.

KY Department of Agriculture. (2016). Farmers' Market. Retrieved July 15, 2017, from http://www.kyagr.com/marketing/farmers-market.html 
Lee, D.-Y., Shannon, K., \& Beaudette, L. A. (2006). Detection of bacterial pathogens in municipal wastewater using an oligonucleotide microarray and real-time quantitative PCR. Journal of Microbiological Methods, 65(3), 453-467. https://doi.org/10.1016/j.mimet.2005.09.008

Levy, D. J., Beck, N. K., Kossik, A. L., Patti, T., Meschke, J. S., Calicchia, M., \& Hellberg, R. S. (2015). Microbial safety and quality of fresh herbs from Los Angeles, Orange County and Seattle farmers' markets. Journal of the Science of Food and Agriculture, 95(13), 2641-2645. https://doi.org/10.1002/jsfa.6996

Scheinberg, J. A., Dudley, E. G., Campbell, J., Roberts, B., DiMarzio, M., DebRoy, C., \& Cutter, C. N. (2017). Prevalence and Phylogenetic Characterization of Escherichia coli and Hygiene Indicator Bacteria Isolated from Leafy Green Produce, Beef, and Pork Obtained from Farmers' Markets in Pennsylvania. Journal of Food Protection, 80(2), 237-244. https://doi.org/10.4315/0362028X.JFP-16-282

U.S. FDA. (2011). Outbreaks - Environmental Assessment: Factors Potentially Contributing to the Contamination of Fresh Whole Cantaloupe Implicated in a Multi-State Outbreak of Listeriosis [WebContent]. Retrieved July 15, 2017, from https://www.fda.gov/food/recallsoutbreaksemergencies/outbreaks/ucm276247.htm

U.S. FDA. (2014a). Bacteriological Analytical Manual Chapter 5 Salmonella [WebContent]. Retrieved May 10, 2017, from https://www.fda.gov/Food/FoodScienceResearch/LaboratoryMethods/ucm070149.htm

U.S. FDA. (2014b). Laboratory Methods - BAM: Salmonella [WebContent]. Retrieved July 15, 2017, from https://www.fda.gov/food/foodscienceresearch/laboratorymethods/ucm070149.htm U.S. FDA. (2015). Final rule on produce safety. Retrieved July 15, 2017, from https://www.fda.gov/downloads/Food/GuidanceRegulation/FSMA/UCM472887.pdf 
U.S. FDA. (2016). Bacteriological Analytical Manual Chapter 10 Detection of Listeria monocytogenes in Foods and Environmental Samples, and Enumeration of Listeria monocytogenes in Foods [WebContent]. Retrieved May 10, 2017, from https://www.fda.gov/Food/FoodScienceResearch/LaboratoryMethods/ucm071400.htm USDA- FSIS. (2016). Microbiology Laboratory Guidebook. Retrieved July 15, 2017, from https://www.fsis.usda.gov/wps/portal/fsis/topics/science/laboratories-andprocedures/guidebooks-and-methods/microbiology-laboratory-guidebook/microbiologylaboratory-guidebook

Viswanath, P., Murugesan, L., Knabel, S. J., Verghese, B., Chikthimmah, N., \& LaBORDE, L. F. (2013). Incidence of Listeria monocytogenes and Listeria spp. in a Small-Scale Mushroom Production Facility. Journal of Food Protection, 76(4), 608-615. https://doi.org/10.4315/0362-028X.JFP-12292

Wood, J. L., Chen, J. C., Friesen, E., Delaquis, P., \& Allen, K. J. (2015). Microbiological Survey of Locally Grown Lettuce Sold at Farmers' Markets in Vancouver, British Columbia. Journal of Food Protection, 78(1), 203-208. https://doi.org/10.4315/0362-028X.JFP-14-199

Z. Vincent, H. Khouryieh, M. Stone, C. Shen, T. William, \& J. Daday. (2015, July). An assessment of food safety practices at farmers market in Kentucky. Presented at the 2015 annual meeting of the Institute of food technologists, Chicago, IL. 


\section{Ch.3 Tables}

Table 1. Average and standard deviation of microbial populations (log CFU/g) measured as aerobic plate counts, total coliforms, and yeasts and molds from tomatoes, peppers, cucumbers, cantaloupes and spinach obtained from farmers' markets in Morgantown, West Virginia and Bowling Green, Kentucky.

\begin{tabular}{cccc}
\hline Sample type (n) & Aerobic plate counts & Total coliforms & Yeasts and molds \\
\hline Tomatoes (64) & $3.7 \pm 1.4^{\mathrm{A}}$ & $3.8 \pm 1.6^{\mathrm{A}}$ & $3.2 \pm 0.9^{\mathrm{A}}$ \\
Peppers (54) & $4.5 \pm 1.0^{\mathrm{A}}$ & $4.0 \pm 1.5^{\mathrm{A}}$ & $3.1 \pm 0.7^{\mathrm{A}}$ \\
Cucumbers (35) & $4.2 \pm 1.3^{\mathrm{A}}$ & $3.7 \pm 2.1^{\mathrm{A}}$ & $3.7 \pm 1.3^{\mathrm{A}}$ \\
Cantaloupes (16) & $4.8 \pm 0.4^{\mathrm{A}}$ & $4.4^{\mathrm{A}} \pm 0.4^{\mathrm{A}}$ & $3.3 \pm 0.4^{\mathrm{A}}$ \\
Spinach (43) & $5.6 \pm 1.1^{\mathrm{B}}$ & $5.4 \pm 0.9^{\mathrm{B}}$ & $4.1 \pm 0.6^{\mathrm{B}}$ \\
\hline
\end{tabular}

Mean values with different capital letters within each column are significantly different $(P<0.0 .5)$ 
Table 2. Prevalence of Salmonella enterica spp. on fresh produce obtained from farmers' markets in Morgantown, West Virginia and Bowling Green, Kentucky.

\begin{tabular}{|c|c|c|c|c|}
\hline \multirow[b]{2}{*}{ Sample type } & \multirow[b]{2}{*}{ No. of vendors } & \multicolumn{3}{|c|}{ No. of positive samples/ No. of samples tested ( $\%$ positive) } \\
\hline & & Total & Morgantown & Bowling Green \\
\hline Tomatoes & 13 & $7 / 64$ (10.9) & $2 / 44(4.5)^{\mathrm{A}}$ & $5 / 20(25)^{\mathrm{B}}$ \\
\hline Peppers & 11 & $10 / 54(18.5)$ & $3 / 40(7.5)^{\mathrm{A}}$ & $7 / 14(50)^{\mathrm{B}}$ \\
\hline Cucumbers & 5 & $0 / 35(0)$ & $0 / 35(0)$ & $--^{\mathrm{a}}$ \\
\hline Cantaloupes & 2 & $9 / 16(56.2)$ & $6 / 12(50.0)^{\mathrm{A}}$ & $3 / 4(75)^{B}$ \\
\hline Spinach & 8 & $8 / 43(18.6)$ & $7 / 31(22.6)^{\mathrm{A}}$ & $1 / 12(8.3)^{\mathrm{B}}$ \\
\hline
\end{tabular}

a Indicates no cucumber samples from Bowling Green were collected due to the off season

Mean values with different capital letters within each row are significantly different $(P<0.0 .5)$ 
Table 3. Prevalence of Listeria spp. and L. monocytogenes on fresh produce obtained from farmers' markets at Morgantown, West Virginia and Bowling Green, Kentucky.

\begin{tabular}{|c|c|c|c|c|c|c|c|}
\hline \multirow{2}{*}{ Sample type } & \multirow{2}{*}{$\begin{array}{l}\text { No. of } \\
\text { vendors }\end{array}$} & \multicolumn{3}{|c|}{$\begin{array}{l}\text { No. of Listeria spp. positive samples/No. of } \\
\text { tested samples }(\%)\end{array}$} & \multicolumn{3}{|c|}{$\begin{array}{l}\text { No. of L. monocytogenes positive samples/No. } \\
\text { of tested samples ( } \%)\end{array}$} \\
\hline & & Total & Morgantown & Bowling Green & Total & Morgantown & Bowling Green \\
\hline Tomatoes & 13 & $1 / 64(1.6)$ & $1 / 44(2.3)^{\mathrm{A}}$ & $0 / 20(0)^{\mathrm{B}}$ & $1 / 64(1.6)$ & $1 / 44(2.3)^{\mathrm{A}}$ & $0 / 20(0)^{\mathrm{B}}$ \\
\hline Peppers & 11 & $3 / 54(5.6)$ & $1 / 40(2.5)^{\mathrm{A}}$ & $2 / 14(14.3)^{\mathrm{B}}$ & $0 / 54(0)$ & $0 / 40(0)^{\mathrm{A}}$ & $0 / 14(0)^{\mathrm{A}}$ \\
\hline Cucumbers & 5 & $2 / 35(5.7)$ & $2 / 35(5.7)$ & $--^{\mathrm{a}}$ & $2 / 35(5.7)$ & $2 / 35(5.7)$ & $--^{\mathrm{a}}$ \\
\hline Cantaloupes & 2 & $2 / 16(12.5)$ & $2 / 12(16.7)^{\mathrm{A}}$ & $0 / 4(0)^{\mathrm{B}}$ & $1 / 16(6.3)$ & $1 / 12(8.3)^{\mathrm{A}}$ & $0 / 4(0)^{\mathrm{B}}$ \\
\hline Spinach & 8 & $0 / 43(0)$ & $0 / 31(0)^{\mathrm{A}}$ & $0 / 12(0)^{\mathrm{A}}$ & $0 / 43(0)$ & $0 / 31(0)^{\mathrm{A}}$ & $0 / 12(0)^{\mathrm{A}}$ \\
\hline
\end{tabular}

${ }^{\mathrm{a}}$ Indicates no cucumber samples from Bowling Green were collected due to the off season

Mean values with different capital letters within each row are significantly different $(P<0.0 .5)$ 


\title{
CHAPTER 4
}

\section{Validation of a Post-harvest Washing Practice with Antimicrobials to Inactivate Salmonella and Listeria monocytogenes}

\begin{abstract}
Due to the high percentage of pathogens detected on farmers' market produce, an evaluation of post-harvest produce washing with various antimicrobials was conducted. Specifically, spinach, tomatoes, green peppers and cucumbers were inoculated with $S$. Typhimurium and Tennessee or L. monocytogenes and washed in tap water, vinegar water (10\%), lactic acid (5\%), a lactic and citric acid blend (2.5\%), and sodium hypochlorite (200 ppm) for $30 \mathrm{sec}$ or unwashed control was evaluated. Vinegar water $(10 \%)$ showed better $(P<0.05)$ reduction of $S$. Typhimurium and Tennessee on tomatoes and cucumbers, and L. monocytogenes on tomatoes and peppers than tap water. The three antimicrobials reached an additional reduction level of 0.9 to 2.7 for $S$. Typhimurium and Tennessee and 0.2 to $1.4 \log$ CFU/g for $L$.

monocytogenes compared to tap water. Lactic acid had the greatest effect $(P<0.05)$ on reduction of $S$. Typhimurium and Tennessee on spinach and green peppers, and sodium hypochlorite was most effective $(P<0.05)$ for reduction of $L$. monocytogenes on cucumbers. The results supplied important information for FM vendors to develop post-harvest protocols to control foodborne pathogens.
\end{abstract}

Keywords: Antimicrobial treatments, fresh produce, Salmonella, lactic acid, citric acid, vinegar, sodium hypochlorite 


\section{Introduction}

Post-harvest produce pathogen control processes are important for small produce growers to reduce pathogens on produce surfaces. The WV Small Farm Center and WV Farmers' Market Association organized two short courses on post-harvest produce safety for small growers from 2015 to 2016 (Shen, 2015, 2016). The short course attendees, especially local farmers' market managers, were very interested in the antimicrobial efficacy of commercial antimicrobial chemicals on produce surfaces, such as vinegar water. The "three-step" washing process (water, water, followed by antimicrobial application) has been suggested to be effective for removal of pathogens from food surfaces to improve on-farm food safety (Strohbehn et al., 2013).

The WV Small Farm Center is also encouraging local small produce growers to apply the "three-step" washing procedure to produce surfaces if their produce is eaten raw or is grown close to the ground (personal communication with Dr. Tom McConnell, Program Leader of the WV Small Farm Center). Effectiveness of antimicrobial chemicals such as chlorine, peracectic acid, lactic acid, acetic acid, citric acid, chlorine dioxide, and ozone has been documented in the new guidelines of the United Fresh Produce Association (Gombas et al., 2017) for use on a commercial scale. However, the efficacy of these antimicrobials for reducing the foodborne pathogen risk has not been validated on locally grown fresh produce.

In this chapter we will assess post-harvest washing practices with antimicrobials to control S. Typhimurium and Tennessee and L. monocytogenes on fresh produce from farmers' markets. 


\section{Materials and Methods}

\subsection{Inoculation and antimicrobial treatment on fresh produce}

Two Salmonella strains, S. Typhimurium ATCC 14028 and S. Tennessee ATCC 10722, and four Listeria monocytogenes strains (ATCC 15213, Scott A 724 [Massachusetts meat outbreak, serotype 4b], L502 [chocolate milk outbreak serotype 1/2b], L2624 and L2625 [cantaloupe outbreak serotype 1/2b]) were used in the washing efficacy studies. Each individual strain was selected from a single colony on Xylose-Lysine-Tergitol 4 (XLT-4, for Salmonella) and Modified Oxford Agar (MOX Agar, for L. monocytogenes), incubated at $35^{\circ} \mathrm{C}, 24 \pm 2 \mathrm{~h}$ and subcultured once $\left(35^{\circ} \mathrm{C}, 24 \pm 2 \mathrm{~h}\right)$ in $10 \mathrm{~mL}$ tryptic soy broth (TSB; Alpha Biosciences, Baltimore, MD, USA). Cultures were combined and harvested by centrifugation (VWR Symphony 4417, VWR International, Radnor, PA; 5,000 × g, $15 \mathrm{~min}$ ), washed twice with $0.1 \% \mathrm{BPW}$ to remove residual media, centrifuged, and re-suspended in 0.1\% BPW. The two Salmonella strains and four L. monocytogenes strains were mixed all together and then diluted in 3 liters of a $0.1 \% \mathrm{BPW}$ solution to obtain a target concentration of $6.5 \log \mathrm{CFU} / \mathrm{mL}$. Spinach (300 g), tomatoes (4 ea.), green peppers (4 ea.) and cucumbers (4 ea.), purchased from WV Morgantown farmers' market, were inoculated by placing the product in a sterile metal bowl containing 3 liter of the inoculum for 5 min. Produce samples were then removed from the inoculum solution and placed in a biosafety cabinet for 30 min to allow for bacterial attachment. Inoculated produce samples were then left unwashed (control) or were immersed for $30 \mathrm{sec}$ in $3 \mathrm{~L}$ of wash solution with manual agitation ( 200 rpm). Wash solution consisted of either in tap water, lactic acid (5\%, Birko, CO, USA), vinegar water (10\%, distilled white vinegar, Heinz Inc., Pittsburgh, PA, USA), lactic/citric acid blend (2.5\%, Veggiexide, Birko, CO, USA), or sodium chlorite (free available chlorine, $200 \mathrm{ppm}$ ). After washing for $30 \mathrm{sec}$, produce samples were then allowed to drain for 5 
min in a sanitized metal mesh tray to drain excess liquid. All fresh produce in one commodity class were washed together.

\subsection{Microbiological analysis}

After washing, each $300 \mathrm{~g}$ spinach sample was divided into 4, $75 \mathrm{~g}$ subsamples, individual tomatoes, green peppers, and cucumbers were placed in separate sterile Whirl-Pak ${ }^{\circledR}$ bags containing $150 \mathrm{~mL}$ of $0.1 \%$ BPW supplemented with $0.1 \%$ sodium thiosulfate (Adler, CainHelfrich, \& Shen, 2016; Fisher Scientific, Springfield, NJ, USA). Spinach suspended in 0.1\% BPW was mechanically homogenized for 2 min in a masticator (IUL Instruments, Barcelona, Spain). Bags of tomato, green pepper and cucumber were shaken vertically 60 times and massaged 60 times to detach cells (Gereffi et al., 2015). The samples were serially diluted 10fold in $0.1 \%$ BPW followed by plating on XLT-4 and MOX agar for enumeration of Salmonella and L. monocytogenes populations, respectively. The XLT-4 plates were incubated at $35^{\circ} \mathrm{C}$ for $24 \mathrm{~h}$, and the MOX plates were incubated at $35^{\circ} \mathrm{C}$ for $48 \mathrm{~h}$ before manually counting colonies.

\subsection{Data analysis}

Produce washing studies were repeated twice, and four samples of each produce were analyzed, for a total of 8 samples per treatment. Average control (untreated) plate counts $\left(\mathrm{N}_{0}\right)$ were divided by the plate count of each individual water or antimicrobial treated sample $(\mathrm{N})$ to provide a reduction ratio $\left(\mathrm{N}_{0} / \mathrm{N}\right)$. The $\log _{10}\left(\mathrm{~N}_{0} / \mathrm{N}\right)$ of the ratios was then used to determine the reduction data, and variances within each treatment were used to calculate the standard deviation. Means were compared at a $\alpha=0.05$ significance level, difference were determined by Tukey HSD. 


\section{Results and Discussion}

\subsection{Efficacy of washing produce without/with antimicrobials to inactivate Salmonella and $L$.}

monocytogenes

Our recent survey showed that $74 \%$ of vendors at the Morgantown WV farmers' market and $84 \%$ of vendors from the Bowling Green KY farmers' market washed their produce before selling it to the public; however, only 9\% (Morgantown) to 26\% (Bowling Green) added antimicrobials, such as chlorine or vinegar water, to their washing solutions (Shen, Norris, Williams, Hagan, \& Li, 2016). There is growing interest, from WV local produce growers, in the application of antimicrobials, especially vinegar water, to fresh produce before selling. Most of the available literature regarding antimicrobial efficacy of commercial antimicrobials, including sodium hypochlorite, organic acids, or peroxyacetic acid produce, is focused on industry scale, fresh cut produce, such as iceberg and romaine lettuce (Akbas \& Ölmez, 2007; Beuchat, Adler, \& Lang, 2004; Lin, Moon, Doyle, \& McWatters, 2002; Stopforth, Mai, Kottapalli, \& Samadpour, 2008). Limited data are available on post-harvest washing practices to control foodborne pathogens on locally grown fresh produce, including spinach, green peppers, cucumbers and tomatoes. From a state and county farmers' market regulatory perspective and to develop new policies and guidelines, it is necessary to gather validated scientific information to support the recommendation of antimicrobials during the wash process. Therefore, in this study, we evaluated the antimicrobial efficacy of vinegar water and several commercial antimicrobials to inactivate Salmonella and L. monocytogenes on various produce from the farmers' market.

Recovery of Salmonella and L. monocytogenes from inoculated fresh produce ranged from 4.0 to 4.9 (Table 4) and 4.6 to $5.3 \log$ CFU/g (Table 5), respectively. Washing spinach in tap water did not significantly reduce ( $>0.05)$ Salmonella and L. monocytogenes populations. In 
contrast washing with water did physically remove $(P<0.05) 0.6$ to 0.9 (Table 4$)$ and 0.8 to 1.1 $\log \mathrm{CFU} / \mathrm{g}$ (Table 5) of Salmonella and L. monocytogenes, respectively, from tomatoes, green peppers and cucumbers. It is possible for the large surface area and its stackable shape of spinach providing more protection for the pathogens from the antimicrobial treatments, causing a smaller reduction comparing to produce with rounded, softer surface with smaller surface area. Our results agree with the previous study of Liao et al. (2010), who reported that washing with water removed $0.5 \log$ of Salmonella Saintpaul from jalapeno peppers.

Vinegar water is widely accepted by WV local farmers' market vendors and small family-based fresh produce processers as an organic sanitizer that can be used to decontaminate fresh produce surfaces. We found washing fresh produce in $10 \%$ food grade vinegar water for 30 sec achieved an additional reduction of 0.3 to $1.0 \mathrm{log}$ CFU/g of Salmonella (Table 4) and 0.4 to $0.9 \log \mathrm{CFU} / \mathrm{g}$ of L. monocytogenes (Table 5) on tomatoes, green peppers, and cucumbers compared to those washed in tap water. However, there was no difference regarding pathogen survival on spinach between tap water and vinegar water treated samples. The results of this study emphasize and verify that washing fresh produce in water, especially in vinegar water, could reduce microbial foodborne pathogens on the surface of locally grown fresh produce.

Chlorine (sodium hypochlorite) is the most commonly used antimicrobials in the fresh produce industry (Shen et al., 2013). However, increasing interest in organic acid antimicrobials, including lactic and citric acids, have been reported (Adler et al., 2016). Veggiecide, a buffered blend of natural lactic acid and citric acid, is verified for effectively inactivating Salmonella on jalapeno peppers (Adler et al., 2016). As expected, commercial antimicrobials, sodium hypochlorite, lactic acid, and lactic/citric acid blend compared to tap water, significantly increase inactivation of Salmonella and L. monocytogenes on fresh produce achieved. For Salmonella, 
sodium hypochlorite, lactic acid, and lactic/citric acid blend achieved an additional reductions $(P<0.05)$ of 1.5 to $2.7,1.6$ to $1.8,0.9$ to 1.9 , and 1.3 to $2.1 \log \mathrm{CFU} / \mathrm{g}$ on spinach, tomatoes, green peppers and cucumbers, respectively, compared to those treated with only tap water (Table 4). Three commercial antimicrobials behaved differently among four fresh produce communities. The greatest $(P<0.05)$ Salmonella reduction was achieved with lactic acid on spinach and green peppers and with sodium hypochlorite on cucumbers (Table 4); whereas, there was no difference $(P>0.05)$ in reduction level on tomatoes among these three antimicrobials. For $L$.

monocytogenes, the application of sodium hypochlorite, lactic acid, and lactic/citric acid blend increased $(P<0.05)$ the reduction levels ranging from 0.7 to $1.1,0.2$ to $1.4,0.6$ to 1.1 , and 0.7 to $1.1 \log \mathrm{CFU} / \mathrm{g}$ on spinach, tomatoes, green peppers, and cucumbers, respectively, in comparison with those from the tap water treatment (Table 5). A similar reduction among these three antimicrobials was observed on spinach, peppers, and cucumbers. The results for sodium hypochlorite $(P<0.05)$ suggest a better reduction of pathogens on tomatoes than lactic acid or the lactic acid/citric acid blend treatment (Table 5).

To improve microbial safety of fresh produce, growers could adopt a post-harvest washing practice, especially the use of vinegar water and commercial antimicrobials. Future studies are needed to validate efficacy of antimicrobials in a pilot scale "three-step" washing process, and estimate whether the application of antimicrobials is economically feasible for locally small produce growers. The results of this study will be of interest to WV and KY growers and county food and agriculture regulatory officials for improving local regulations directed at farmers' markets. Furthermore, these results will be of interest to extension specialist/agents who are developing and implementing produce safety training programs, such 
as a post-harvest produce sanitizing short course. These data can assist local farmers' market associations in the development of training materials for market managers and vendors. 


\section{References}

Adler, J. M., Cain-Helfrich, E. D., \& Shen, C. (2016). Reductions in Natural Microbial Flora, Nonpathogenic Escherichia coli, and Pathogenic Salmonella on Jalapeno Peppers Processed in a Commercial Antimicrobial Cabinet: A Pilot Plant Trial. Journal of Food Protection, 79(11), 1854-1859. https://doi.org/10.4315/0362-028X.JFP-16-222

Akbas, M. y., \& Ölmez, H. (2007). Inactivation of Escherichia coli and Listeria monocytogenes on iceberg lettuce by dip wash treatments with organic acids. Letters in Applied Microbiology, 44(6), 619-624. https://doi.org/10.1111/j.1472-765X.2007.02127.x

Beuchat, L. R., Adler, B. B., \& Lang, M. M. (2004). Efficacy of chlorine and a peroxyacetic acid sanitizer in killing Listeria monocytogenes on iceberg and romaine lettuce using simulated commercial processing conditions. Journal of Food Protection, 67(6), 12381242.

Gereffi, S., Sreedharan, A., \& Schneider, K. R. (2015). Control of Salmonella CrossContamination between Green Round Tomatoes in a Model Flume System. Journal of Food Protection, 78(7), 1280-1287. https://doi.org/10.4315/0362-028X.JFP-14-524

Gombas, D., Luo, Y., Brennan, J., Shergill, G., Petran, R., Walsh, R., ... Deng, K. (2017). Guidelines To Validate Control of Cross-Contamination during Washing of Fresh-Cut Leafy Vegetables. Journal of Food Protection, 80(2), 312-330. https://doi.org/10.4315/0362-028X.JFP-16-258

Liao, C.-H., Cooke, P. h., \& Niemira, B. a. (2010). Localization, Growth, and Inactivation of Salmonella Saintpaul on Jalapeño Peppers. Journal of Food Science, 75(6), M377M382. https://doi.org/10.1111/j.1750-3841.2010.01667.x 
Lin, C.-M., Moon, S. S., Doyle, M. P., \& McWATTERS, K. H. (2002). Inactivation of Escherichia coli O157: H7, Salmonella enterica serotype Enteritidis, and Listeria monocytogenes on lettuce by hydrogen peroxide and lactic acid and by hydrogen peroxide with mild heat. Journal of Food Protection, 65(8), 1215-1220.

Shen, C. (2015, February). Post-harvest Sanitize and Water Quality. Presented at the West Virginia Small Farm Conference, Charleston Civic Center, West Virginia.

Shen, C. (2016, March). Post-harvest handling. Presented at the West Virginia Farmers Market Manager Training, West Virginia State University, Charleston, West Virginia.

Shen, C., Luo, Y., Nou, X., Wang, Q., \& Millner, P. (2013). Dynamic Effects of Free Chlorine Concentration, Organic Load, and Exposure Time on the Inactivation of Salmonella, Escherichia coli O157:H7, and Non-O157 Shiga Toxin-Producing E. coli. Journal of Food Protection, 76(3), 386-393. https://doi.org/10.4315/0362-028X.JFP-12-320

Shen, C., Norris, P., Williams, O., Hagan, S., \& Li, K. (2016). Generation of chlorine byproducts in simulated wash water. Food Chemistry, 190, 97-102. https://doi.org/10.1016/j.foodchem.2015.04.146

Stopforth, J. D., Mai, T., Kottapalli, B., \& Samadpour, M. (2008). Effect of acidified sodium chlorite, chlorine, and acidic electrolyzed water on Escherichia coli O157: H7, Salmonella, and Listeria monocytogenes inoculated onto leafy greens. Journal of Food Protection, 71(3), 625-628.

Strohbehn, C., Mendonca, A., Wilson, L., Domoto, P., Smith, M., Brehm-Stecher, B., \& Shaw, A. M. (2013). On-farm Food Safety: Cleaning and Sanitizing Guide. Retrieved from http://lib.dr.iastate.edu/cgi/viewcontent.cgi?article $=1101 \&$ context=extension_families_p ubs 


\section{Ch 4 tables}

2 Table 4. Survival and reduction of Salmonella Typhimurium and Tennessee populations $(\log \mathrm{CFU} / \mathrm{g} \pm \mathrm{standard}$ deviation, $\mathrm{n}=8)$ from 3 spinach, tomatoes, green peppers and cucumbers after being washed with tap water, vinegar (10\%), sodium hypochlorite (SH, 200

4 ppm), lactic acid (LA, 5.0\%), and lactic/citric acid blend (LCA, 2.5\%) solutions for 30 sec.

5

\begin{tabular}{|c|c|c|c|c|c|c|c|c|}
\hline \multirow[b]{2}{*}{ Treatment } & \multicolumn{2}{|c|}{ Spinach } & \multicolumn{2}{|c|}{ Tomatoes } & \multicolumn{2}{|c|}{ Green peppers } & \multicolumn{2}{|c|}{ Cucumbers } \\
\hline & Survival & Reduction & Survival & Reduction & Survival & Reduction & Survival & Reduction \\
\hline Control & $4.9 \pm 0.9^{\mathrm{A}}$ & $--^{\mathrm{a}}$ & $4.4 \pm 0.2^{\mathrm{A}}$ & $--^{\mathrm{a}}$ & $4.2 \pm 0.7^{\mathrm{A}}$ & $--^{\mathrm{a}}$ & $4.0 \pm 0.3^{\mathrm{A}}$ & $--^{\mathrm{a}}$ \\
\hline Tap water & $4.8 \pm 0.3^{\mathrm{AB}}$ & $0.1 \pm 0.3^{\mathrm{A}}$ & $3.6 \pm 0.5^{\mathrm{B}}$ & $0.8 \pm 0.5^{\mathrm{A}}$ & $3.6 \pm 0.2^{\mathrm{B}}$ & $0.6 \pm 0.2^{\mathrm{A}}$ & $3.1 \pm 0.7^{\mathrm{B}}$ & $1.0 \pm 0.7^{\mathrm{A}}$ \\
\hline Vinegar $(10 \%)$ & $4.6 \pm 0.8^{\text {В }}$ & $0.3 \pm 0.5^{\mathrm{A}}$ & $2.8 \pm 0.4^{\mathrm{C}}$ & $1.6 \pm 0.4^{\mathrm{B}}$ & $3.3 \pm 0.3^{\mathrm{B}}$ & $1.0 \pm 0.3^{\mathrm{B}}$ & $2.1 \pm 0.5^{\mathrm{C}}$ & $2.0 \pm 0.5^{\mathrm{B}}$ \\
\hline SH (200 ppm) & $3.3 \pm 0.2^{\mathrm{C}}$ & $1.6 \pm 0.2^{\mathrm{B}}$ & $1.8 \pm 1.0^{\mathrm{D}}$ & $2.6 \pm 1.0^{\mathrm{C}}$ & $2.5 \pm 0.5^{\mathrm{C}}$ & $1.7 \pm 0.5^{\mathrm{C}}$ & $1.0 \pm 0.9^{\mathrm{D}}$ & $3.0 \pm 0.9^{\mathrm{C}}$ \\
\hline LA $(5.0 \%)$ & $2.1 \pm 0.6^{\mathrm{D}}$ & $2.8 \pm 0.6^{\mathrm{C}}$ & $2.0 \pm 0.5^{\mathrm{D}}$ & $2.4 \pm 0.5^{\mathrm{C}}$ & $1.7 \pm 0.6^{\mathrm{D}}$ & $2.5 \pm 0.5^{\mathrm{D}}$ & $1.5 \pm 0.6^{\mathrm{E}}$ & $2.6 \pm 0.6^{\mathrm{D}}$ \\
\hline LCA $(2.5 \%)$ & $2.8 \pm 0.7^{\mathrm{E}}$ & $2.1 \pm 0.7^{\mathrm{D}}$ & $2.0 \pm 0.6^{\mathrm{D}}$ & $2.4 \pm 0.6^{\mathrm{C}}$ & $2.7 \pm 0.5^{\mathrm{C}}$ & $1.5 \pm 0.6^{\mathrm{C}}$ & $1.8 \pm 0.5^{\mathrm{E}}$ & $2.2 \pm 0.5^{\mathrm{D}}$ \\
\hline
\end{tabular}

$6 \quad{ }^{\mathrm{a}}$ Indicates no reduction value available.

7 Mean values with different uppercase letters within each column are significantly different $(P<0.05)$.

8 
9 Table 5. Survival and reduction of Listeria monocytogenes populations ( $\log \mathrm{CFU} / \mathrm{g} \pm$ standard deviation, $\mathrm{n}=8)$ from spinach,

10 tomatoes, green peppers and cucumbers after being washed with tap water, vinegar (10\%), sodium hypochlorite (SH, $200 \mathrm{ppm})$, lactic

11 acid (LA, 5.0\%), and lactic/citric acid blend (LCA, 2.5\%) solutions for $30 \mathrm{sec}$.

12

\begin{tabular}{|c|c|c|c|c|c|c|c|c|}
\hline \multirow[b]{2}{*}{ Treatment } & \multicolumn{2}{|c|}{ Spinach } & \multicolumn{2}{|c|}{ Tomatoes } & \multicolumn{2}{|c|}{ Green peppers } & \multicolumn{2}{|c|}{ Cucumbers } \\
\hline & Survival & Reduction & Survival & Reduction & Survival & Reduction & Survival & Reduction \\
\hline Control & $5.3 \pm 0.8^{\mathrm{A}}$ & $--^{\mathrm{a}}$ & $4.6 \pm 0.3^{\mathrm{A}}$ & $--^{\mathrm{a}}$ & $5.3 \pm 0.5^{\mathrm{A}}$ & $--^{\mathrm{a}}$ & $4.7 \pm 0.2^{\mathrm{A}}$ & $--^{\mathrm{a}}$ \\
\hline Tap water & $4.9 \pm 0.4^{\mathrm{B}}$ & $0.4 \pm 0.4^{\mathrm{A}}$ & $3.8 \pm 0.3^{\mathrm{B}}$ & $0.8 \pm 0.3^{\mathrm{A}}$ & $4.2 \pm 0.2^{\mathrm{B}}$ & $1.1 \pm 0.2^{\mathrm{A}}$ & $3.9 \pm 0.6^{\mathrm{B}}$ & $0.8 \pm 0.6^{\mathrm{A}}$ \\
\hline Vinegar $(10 \%)$ & $4.9 \pm 0.5^{\mathrm{B}}$ & $0.4 \pm 0.5^{\mathrm{A}}$ & $3.4 \pm 0.3^{\mathrm{C}}$ & $1.2 \pm 0.3^{\mathrm{B}}$ & $3.8 \pm 0.4^{\mathrm{C}}$ & $1.5 \pm 0.4^{\mathrm{B}}$ & $4.0 \pm 0.9^{\mathrm{B}}$ & $0.7 \pm 0.9^{\mathrm{B}}$ \\
\hline SH (200 ppm) & $3.8 \pm 0.2^{\mathrm{C}}$ & $1.5 \pm 0.2^{\mathrm{B}}$ & $2.4 \pm 0.6^{\mathrm{D}}$ & $2.2 \pm 0.6^{\mathrm{C}}$ & $3.1 \pm 0.4^{\mathrm{D}}$ & $2.2 \pm 0.4^{\mathrm{C}}$ & $3.1 \pm 1.3^{\mathrm{C}}$ & $1.6 \pm 1.3^{\mathrm{CD}}$ \\
\hline LA $(5.0 \%)$ & $4.0 \pm 0.7^{\mathrm{C}}$ & $1.4 \pm 0.7^{\mathrm{B}}$ & $3.6 \pm 0.6^{\mathrm{C}}$ & $1.0 \pm 0.6^{\mathrm{D}}$ & $3.1 \pm 0.8^{\mathrm{D}}$ & $2.1 \pm 0.8^{\mathrm{C}}$ & $2.8 \pm 0.5^{\mathrm{C}}$ & $1.9 \pm 0.5^{\mathrm{C}}$ \\
\hline $\operatorname{LCA}(2.5 \%)$ & $4.2 \pm 0.9^{\mathrm{C}}$ & $1.2 \pm 0.9^{\mathrm{B}}$ & $3.4 \pm 0.1^{\mathrm{C}}$ & $1.2 \pm 0.1^{\mathrm{D}}$ & $3.6 \pm 0.2^{\mathrm{C}}$ & $1.7 \pm 0.2^{\mathrm{B}}$ & $3.2 \pm 0.6^{\mathrm{C}}$ & $1.5 \pm 0.6^{\mathrm{D}}$ \\
\hline
\end{tabular}

13 a Indicates no reduction value available.

14 Mean values with different uppercase letters within each column are significantly different $(P<0.0 .5)$ 
